\title{
Long non-coding RNAs in lung cancer: implications for lineage plasticity-mediated TKI resistance
}

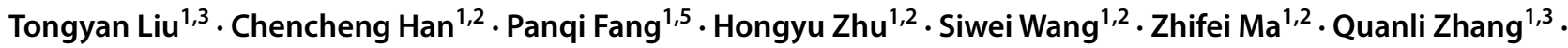 \\ Wenjia Xia ${ }^{1} \cdot$ Jie Wang ${ }^{1,3,4} \cdot$ Lin Xu ${ }^{1} \cdot$ Rong Yin ${ }^{1,3,4}$
}

Received: 22 June 2020 / Revised: 15 October 2020 / Accepted: 23 October 2020 / Published online: 10 November 2020

(c) The Author(s) 2020

\begin{abstract}
The efficacy of targeted therapy in non-small-cell lung cancer (NSCLC) has been impeded by various mechanisms of resistance. Besides the mutations in targeted oncogenes, reversible lineage plasticity has recently considered to play a role in the development of tyrosine kinase inhibitors (TKI) resistance in NSCLC. Lineage plasticity enables cells to transfer from one committed developmental pathway to another, and has been a trigger of tumor adaptation to adverse microenvironment conditions including exposure to various therapies. More importantly, besides somatic mutation, lineage plasticity has also been proposed as another source of intratumoural heterogeneity. Lineage plasticity can drive NSCLC cells to a new cell identity which no longer depends on the drug-targeted pathway. Histological transformation and epithelial-mesenchymal transition are two well-known pathways of lineage plasticity-mediated TKI resistance in NSCLC. In the last decade, increased re-biopsy practice upon disease recurrence has increased the recognition of lineage plasticity induced resistance in NSCLC and has improved our understanding of the underlying biology. Long non-coding RNAs (lncRNAs), the dark matter of the genome, are capable of regulating variant malignant processes of NSCLC like the invisible hands. Recent evidence suggests that lncRNAs are involved in TKI resistance in NSCLC, particularly in lineage plasticity-mediated resistance. In this review, we summarize the mechanisms of lncRNAs in regulating lineage plasticity and TKI resistance in NSCLC. We also discuss how understanding these themes can alter therapeutic strategies, including combination therapy approaches to overcome TKI resistance.
\end{abstract}

Keywords Non-small-cell lung cancer $\cdot$ Tyrosine kinase inhibitors $\cdot$ Long non-coding RNAs $\cdot$ Lineage plasticity

\section{Abbreviations}

NSCLC Non-small-cell lung cancer

lncRNA Long non-coding RNA

TKI Tyrosine kinase inhibitors

EGFR Epidermal growth factor receptor

BRAF Serine/threonine-protein kinase b-raf

Tongyan Liu, Chencheng Han, Panqi Fang and Hongyu Zhu contributed equally to the paper.

Rong Yin

rong_yin@njmu.edu.cn

1 Department of Thoracic Surgery, Jiangsu Cancer Hospital and Jiangsu Institute of Cancer Research and The Affiliated Cancer Hospital of Nanjing Medical University, Jiangsu Key Laboratory of Molecular and Translational Cancer Research, Collaborative Innovation Center for Cancer Personalized Medicine, Nanjing, China

2 The Fourth Clinical College of Nanjing Medical University, Nanjing, China
ALK Anaplastic lymphoma kinase

TME Tumor microenvironment

EZH2 Enhancer of zeste homolog 2

ATL-1 Atractylodes macrocephula Koidz atractylenolide 1

STAT3 Signal transducer and activator of transcription

PI3K Phosphatidylinositol 3-kinase

3 Department of Scientific Research, Jiangsu Cancer Hospital and Jiangsu Institute of Cancer Research and The Affiliated Cancer Hospital of Nanjing Medical University, Jiangsu Key Laboratory of Molecular and Translational Cancer Research, Nanjing, China

4 Jiangsu Biobank of Clinical Resources, Nanjing 210009, China

5 Department of Clinical Pharmacy, School of Basic Medical Sciences and Clinical Pharmacy, China Pharmaceutical University, Nanjing 210009, China 


$\begin{array}{ll}\text { SCLC } & \text { Small-cell lung cancer } \\ \text { EMT } & \text { Epithelial-to-mesenchymal transition } \\ \text { NCAM1 } & \text { Neural cell adhesion molecule 1 } \\ \text { RB1 } & \text { RB transcriptional corepressor 1 } \\ \text { TP53 } & \text { Tumor protein p53 } \\ \text { CRPC } & \text { Castration-resistant prostate cancer } \\ \text { AR } & \text { Androgen receptor } \\ \text { NEPC } & \text { Neuroendocrine prostate cancer } \\ \text { ZEB } & \text { Zinc finger E-box-binding homeobox } \\ \text { TGF } \beta & \text { Transforming growth factor- } \beta \\ \text { IL-6 } & \text { Interleukin 6 } \\ \text { LSD1 } & \text { Lysine-specific demethylase 1 } \\ \text { DNMT1 } & \text { DNA methyltransferase 1 } \\ \text { CDKN1A } & \text { Cyclin-dependent kinase inhibitor 1A } \\ \text { YAP1 } & \text { Yes-associated protein 1 } \\ \text { PRC2 } & \text { Polycomb repressive complex 2 } \\ \text { REST } & \text { RE1-slienicng transcription factor } \\ \text { TFBS } & \text { Transcription factor biding site } \\ \text { LUAD } & \text { Lung adenocarcinoma } \\ \text { E2F1 } & \text { E2F transcription factor 1 } \\ \text { INSM1 } & \text { Insulinoma-associated-1 } \\ \text { ASCL } & \text { Achaete-scure complex homolog 1 } \\ \text { ASH1 } & \text { Achaete-scute homolog 1 } \\ \text { CAF } & \text { Cancer-associated fibroblast } \\ \text { HGF } & \text { Hepatocyte growth factor } \\ \text { MET } & \text { Mesenchymal-epithelial transition factor } \\ & \text { receptor } \\ \text { GAS6 } & \text { Growth arrest specific 6 } \\ \text { EGF } & \text { Epidermal growth factor } \\ \text { HB-EGF } & \text { EGF-like growth factor } \\ \text { ECM } & \text { Extracellular matrix } \\ \text { CXCL12 } & \text { CXC-chemokine ligand 12 } \\ \text { TAM } & \text { Tumor-associated macrophage } \\ \text { MAPK } & \text { Mitogen activated kinase-like protein } \\ \text { NF- } B \text { B } & \text { Nuclear factor kappa B } \\ \text { RAS } & \text { Resistance to audiogenic seizures (RAS) } \\ \text { COX2 } & \text { Cytochrome coxidase subunit II } \\ \text { PGE } 2 & \text { Nr5a1 enhancer region in intron 6 } \\ \text { HIF1 } \alpha & \text { Hypoxia-inducible factor 1 } \alpha \\ \text { VEGF } & \text { Vascular endothelial growth factor } \\ \text { PDL1 } & \text { Programmed cell death 1 ligand 1 } \\ \text { HDAC } & \text { Type-2 histone deacetylase 2 } \\ \text { H3K9me3 } & \text { Trimethylation of lysine 9 on histone } \\ & \end{array}$

\section{Introduction}

Lung cancer is the leading cause of cancer-associated mortality worldwide, with non-small-cell lung cancer (NSCLC) as the main histological subtype with a poor 5 year survival [1]. Improved understanding of the molecular classification of lung cancer has revolutionized the treatment of NSCLC. Almost two-thirds of patients with NSCLC are oncogene addicted, approximately half of whom are exquisitely sensitive to targeted therapies [2,3]. These include activating mutations or fusions in epidermal growth factor receptor (EGFR), serine/threonine-protein kinase b-raf (BRAF), anaplastic lymphoma kinase (ALK), and ROS1 receptor tyrosine kinase [3].

Although agents that target the tyrosine kinase domain of these oncogenes improve clinical outcomes of patients with NSCLC, responses to these drugs are generally temporary and limited by emergence of resistance [4]. Resistance to tyrosine kinase inhibitors (TKI) are generally associated with acquired somatic mutations, including genetic alterations that enable bypassing target inhibition through ineffective binding of the drugs, as well as activation of collateral or alternative survival pathways [3, 5, 6]. In addition to these genetic mechanisms of drug resistance, non-mutational mechanisms termed lineage plasticity are also associated with TKI resistance. Lineage plasticity refers to as the ability of cells transferring from one committed developmental pathway to another. It enables the adaptation and survival of tumors under adverse conditions including hypoxia and targeted therapies. Therefore, it is proposed as a mechanism of tumor cells escape from targeted dependency. Lineage plasticity can be both dependent on and a driver of intratumoral heterogeneity $[7,8]$. In contrast to genetic mechanisms of TKI resistance, lineage plasticity-associated resistance primarily relies on phenotype switching, with one single genotype gives rise to different phenotypes upon drug treatment. It enables cancer cells to reversibly convert to new or hybrid lineages that is independent of TKI-targeted pathway [9].

Data from single-cell profiling and lineage tracing technologies suggest that a single cell can give rise to multiple states. Mechanistically, epigenetic modifications and transcriptomic transitions may mediate the emergence of new cell states. Long non-coding RNAs (lncRNAs) the dark matter of the genome, are capable of regulating variant malignant processes of NSCLC through epigenetic modification [10]. Importantly, lncRNAs often offer distinct advantages over proteins for some forms of epigenetic regulation [11]. Recent studies show the transcriptional heterogeneity regulated by lncRNAs might drive the phenotypic switch from one histological category to another, contributing to the lineage plasticity-mediated TKI resistance.

Targeting lineage plasticity provides a new opportunity to prevent the emergence of drug-tolerant cell states and enables TKI to achieve deeper responses. In this review, we performed a literature review covering the publication of the last 15 years on the topic of "long non-coding RNAs regulated lineage plasticity in lung cancer". The keywords used for searching were "cell plasticity", "cancer" and "non-coding RNAs". We summarize current understanding of lineage plasticity as a mechanism of TKI resistance in NSCLC and discuss the implications of lncRNAs in lineage plasticity. 
Finally, we also discuss potential therapeutic strategies to circumvent lineage plasticity in NSCLC.

\section{Lineage plasticity in response to targeted therapies}

Lineage plasticity, the ability of cells to reversibly transfer from a certain developmental pathway to another, has been regarded as a source of intratumoral heterogeneity and of tumor adaptation to adverse tumor microenvironment such as hypoxia and exposure to targeted therapies [7]. Histological transformation of adenocarcinomas to neuroendocrine and epithelial-mesenchymal transition are two wellknown phenotypes of lineage plasticity in NSCLC upon TKI treatment [7, 12]. NSCLC cells has been reported to hijack developmental process involved in epigenetic modification and transcriptional reprogramming to become phenotypically plastic, and reversibly transform into one or several drug-tolerant cell identities [13, 14]. Interestingly, the emergence of slow-cycling tumors cells is primarily considered as the first state before histological transformation and further reprogramming into a drug-resistant state $[15$, 16]. Adenocarcinomas with concomitant inactivation of RB1 and TP53 are more likely to transdifferentiate into neuroendocrine tumors in NSCLC [17-20]. Furthermore, loss of lung lineage-specifying transcription factor gene Nkx2-1, overexpression of lineage-specific transcription factors such as SOX genes, and dysregulation of epigenetic regulators such as histone methyltransferase, changes of key signaling pathways (IL-6-STAT3 or RXR, etc.), as well as interactions with tumor microenvironment (TME) have been associated with intratumoural heterogeneity and lineage plasticitymediated drug resistance [7, 14] (Fig. 1).

\section{Histological transformation}

Histological transformation also referred to as transdifferentiation, which presents the process that cells convert from one lineage to another [21]. Targeted therapy-induced neuroendocrine transdifferentiation has been particularly described in NSCLC and prostate cancer [12, 22]. The transformation of EGFR-mutant adenocarcinoma to a SCLC histology was first reported in a 45-year-old woman with EGFR-mutant adenocarcinoma who underwent erlotinib treatment for 18 months before relapse with the features of SCLC, and positive immunostaining of neural cell adhesion molecule 1 (NCAM1), chromogranin A and synaptophysin [23]. In rare cases, NSCLC could adopt to other neuroendocrine histology, for instance, large cell neuroendocrine carcinoma and small and large cell carcinoma [19]. Transformation to sarcomatoid carcinoma has also been observed in ALK-rearranged NSCLC in resistant to crizotinib. Importantly, the transformed SCLC tumor samples maintained their original mutation [23], which indicates these tumors were emerging from the original adenocarcinoma, rather than de novo cancers. Genetically, NSCLC cells with RB1 and TP53 loss are more likely to transdifferentiate towards a neuroendocrine identity upon TKI treatment $[17,18]$. Similar observations were made in castration-resistant prostate cancer (CRPC), with approximately one-quarter of CRPC acquire androgen receptor (AR) independent resistant through phenotypic switching [22]. These AR-independent

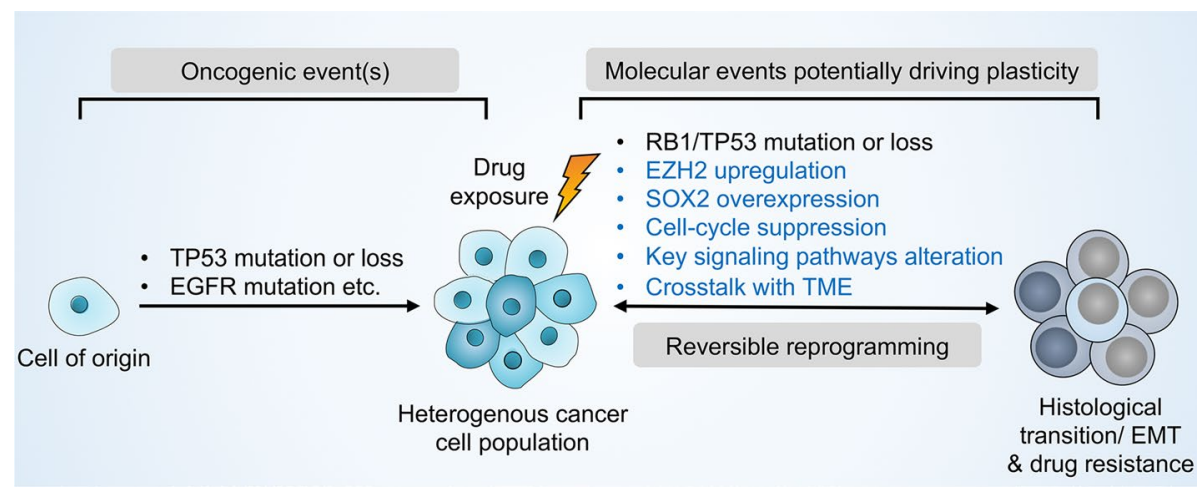

Fig. 1 Lineage plasticity lead to TKI resistance in NSCLC. Upon targeted therapies, various molecular events can promote lineage plasticity, thereby driving intratumoural heterogeneity and drug resistance. RB1 and TP53 mutation or loss NSCLC cells are more likely to transdifferentiate into small cell tumors. Increased histone-modifying enzymes, such as enhancer of zeste homologue 2 (EZH2) and lineage-associated transcription factors, such as SOX family genes mediates the reprogramming of NSCLC into slow-cycling, drugtolerant cell states. These slow-cycling, drug-tolerant cells generally present neuroendocrine differentiation and epithelial-to-mesenchymal transition (EMT). Alterations of key signaling pathways and crosstalk with the tumor microenvironment also control lineage plasticity. Collectively, the plasticity-permissive molecular environment under the pressure of targeted therapies trigger the intratumoural clones presenting an alternative histology to that initially diagnosed, which might become the predominant cell type and exhibit drug resistance. Blue font: lncRNA-mediated molecular events that promote lineage plasticity 
CRPC tumors are referred to as neuroendocrine prostate cancer (NEPC) [22].

\section{Epithelial-mesenchymal transition}

Epithelial-mesenchymal transition (EMT) is another type of tumor cell plasticity related to TKI resistance [12, 24], which tumor cells lose their epithelial features and acquire cellular alterations favoring more invasive, mesenchymal properties. Mesenchymal characteristics were observed in vitro and in vivo EGFR-mutant lung cancer models that acquired resistance to first-generation EGFR-TKI with no genetic alterations [25, 26]. Moreover, tumor biopsy samples from EGFR-TKI resistance patients presented increased vimentin expression and downregulated E-cadherin expression compared with tumor tissues taken before TKI treatment. Importantly, tumor cells undergo epithelial-mesenchymal plasticity retain their original mutation spectrum, indicating EMT as a mechanism of TKI resistance [12, 27]. The precise mechanism of epithelial-mesenchymal plasticity remains to be elucidated. Increased levels of pleiotropic signaling factors, such as transforming growth factor- $\beta$ (TGF- $\beta$ ), epidermal growth factor (EGF), hepatocyte growth factor (HGF), NOTCH, fibroblast growth factor (FGF) and WNT ligands can initiate a signaling cascade resulting the expression of EMT transcription factors [13]. Furthermore, reduced expression of proapoptotic proteins such as PUMA [28] and increased drug efflux [29] have also been reported to associate with EMT process upon TKI treatment.

\section{Deregulated IncRNAs involved in lineage plasticity upon targeted therapies}

\section{Neuroendocrine transdifferentiation-associated IncRNAs}

Clonal analysis showed that complete loss of both RB1 and TP53 may predict neuroendocrine transdifferentiation in NSCLC upon EGFR-TKI treatment [18]. However, cell lines and mouse model studies of lung and prostate cancer suggested that inactivation of RB1 or TP53 alone is not sufficient for their histological transformation or effect their sensitivity to EGFR-TKI [30-32]. Additionally, epigenetic states, specially, lncRNAs are involved in cell-fate determination [33]. Crea et al. identified the first NEPC-associated IncRNA-MIAT, which contributed to the neuroendocrine transdifferentiation of CRPC [34]. Moreover, Ramnarine et al. identified IncRNAs FENDRR, H19, LINC00514, LINC00617, and SSTR5-AS1 to be implicated in the development of NEPC [35]. Altogether, these data suggest lncRNAs can be strong candidate for clinical biomarkers and therapeutic targets in preventing neuroendocrine transdifferentiation in CRPC. Nevertheless, lncRNAs associated with neuroendocrine transformation in NSCLC in response to TKI treatment warrant further investigation. (Table 1).

\section{EMT-associated IncRNAs}

EMT is a dynamic process which tumor cells obtain phenotypic changes through epigenetic modifications [36]. Emerging evidence highlights the involvement of lncRNAs in EMT process in NSCLC [37].

Recently, a group of IncRNAs have been shown to promote drug resistance by acting as molecular decoys to sequester miRNAs associated with EMT. For example, LINC00673, CAR10, XIST, LINC81507, TTN-AS1, LINC00858, H19, SOX20T, LINC00483, PRNCR1, SNHG6, ATB and alternative splicing-generated lncRNAPNUTS [38] are shown to sequester miRNAs from binding EMT associated genes, such as zinc finger E-box binding homeobox 1 and 2 (ZEB1 and ZEB2), thereby initiate EMT in NSCLC [39-46]. Increased levels of transforming growth factor- $\beta$ (TGF $\beta$ ) are reported to facilitate EMT via interleukin-6 (IL-6) in EGFR TKI-resistant NSCLC cells [47]. Several profiling studies have identified the roles of TGF $\beta$ regulated lncRNAs such as ELIT-1, TBILA, LINP and HOTAIR in promoting EMT in NSCLC cell lines [48-51]. Mechanistically, TGF $\beta$-activated lncRNA ELIT-1 can bound to Smad3 and improved Smad-responsive promoter activities by recruiting $S$ mad3 to the promoters of its target genes, which include Snail, and ELIT itself. Thus, ELIT-1 forms a positive feedback loop to promote TGF $\beta / \mathrm{Smad} 3$ signaling pathway and, therefore, promote EMT progression [48]. NORAD, a cytoplasmic long non-coding RNA is also reported to promote TGF $\beta$-induced EMT in NSCLC cell lines [52]. It is shown to enhance the physical interaction of importin $\beta 1$ with Smads, thereby promoting the nuclear accumulation of Smad complexes induced by TGF $\beta$. Furthermore, many lncRNAs associate with epigenetic regulators to regulate EMT. For instance, lncRNA MEG3 is able to recruit EZH2 and epigenetically silencing $\mathrm{CDH} 1$ and miR-200 family in NSCLC cell lines [53]. Similarly, MALAT1 can also recruit EZH2 to silence E-cadherin and, therefore, induce EMT in NSCLC [54]. LncRNA-FEZF1AS1 was shown to epigenetically repress E-cadherin by binding with lysine-specific histone demethylase 1 (LSD1) and EZH2 in NSCLC cells [55]. HOXA11-AS1 was reported to recruit EZH2 and DNA methyltransferase 1 (DNMT1) to the promoter of miR200b and inactivate miR200b, thereby promoting EMT in NSCLC [56]. In contrast, a number of epigenetic upregulated lncRNAs can inhibit EMT through histone modification in NSCLC [57, 58]. For example, lncRNA-BANCR inhibits EMT through histone acetylation [58]. Most TGF $\beta$-regulated lncRNA were reported to 


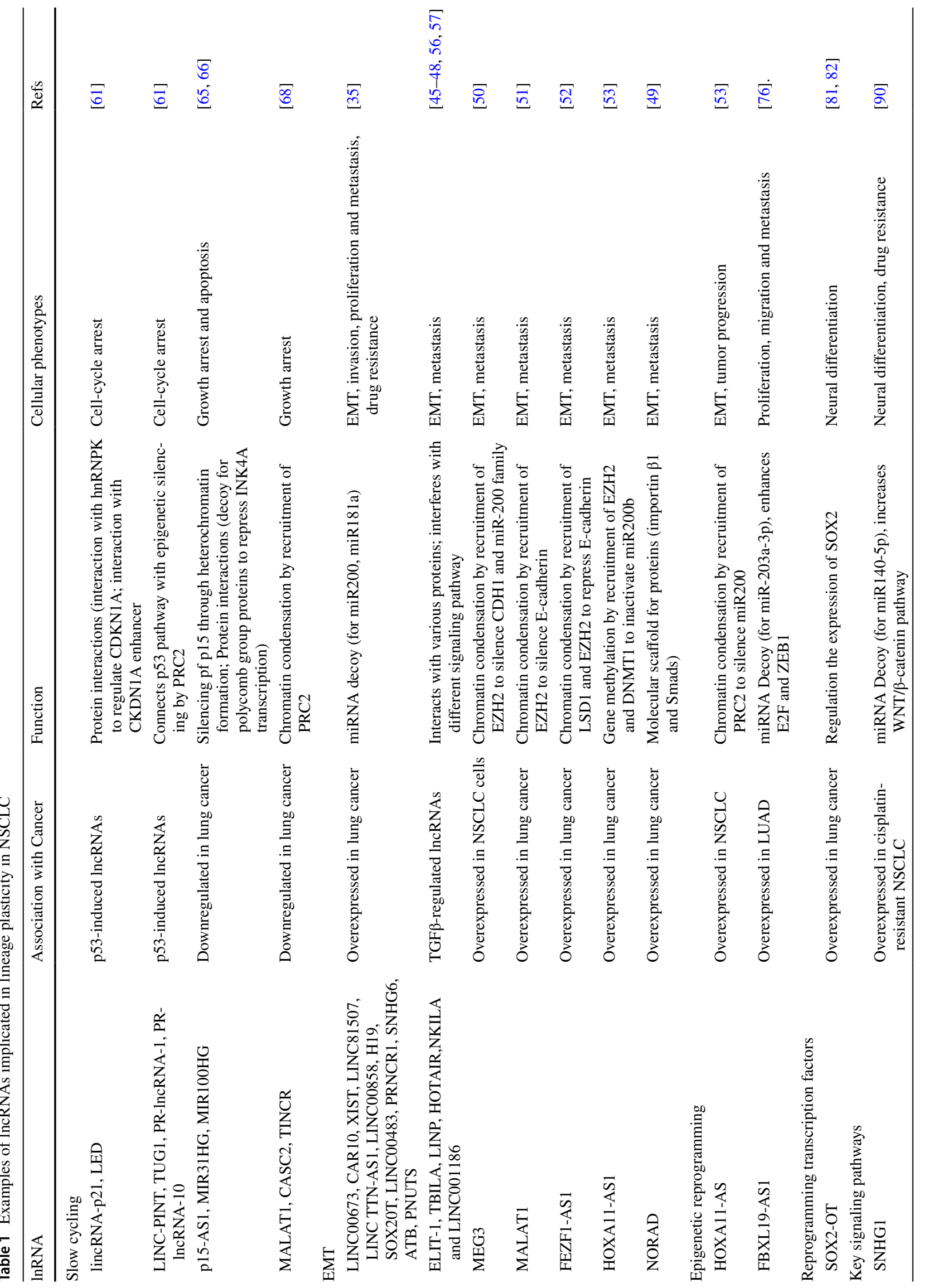




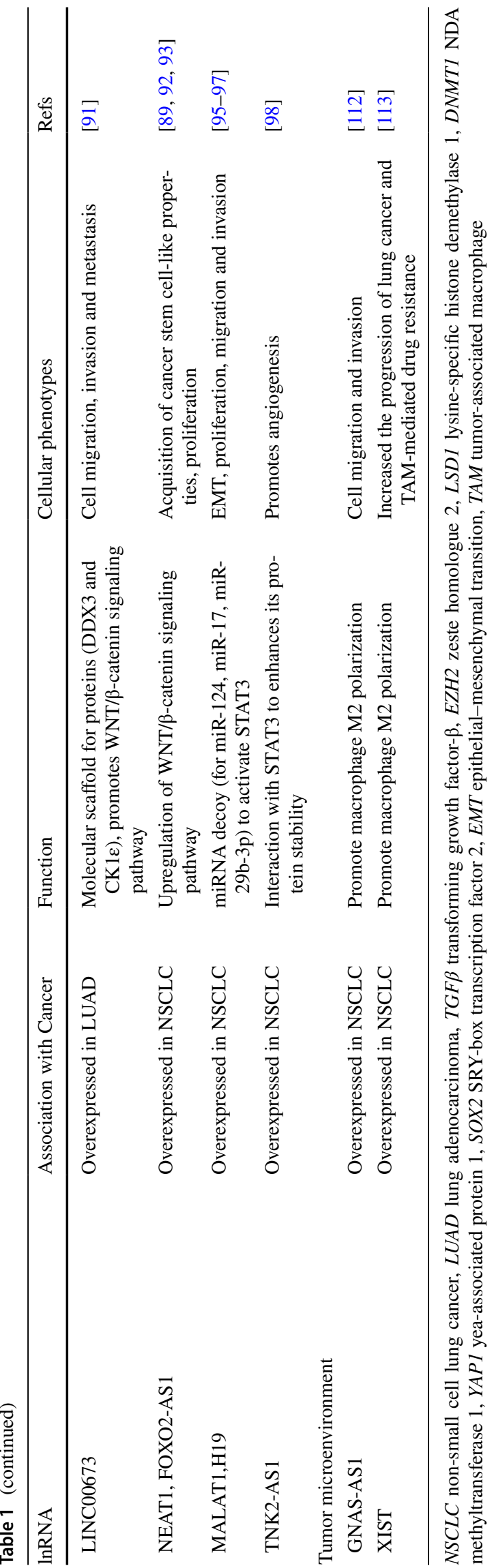

promote EMT, however, TGF $\beta$-regulated lnRNAs NKILA and LINC001186 are reported to inhibit EMT by suppressing the expression of Snail [59, 60]. Targeting EMT-associated lncRNAs may restore the sensitivity to TKI, further studies are needed. (Table 1).

\section{Mechanisms of IncRNA-mediated lineage plasticity}

The molecular mechanisms underlying lineage plasticitymediated TKI resistance remain to be fully established. However, tumor cells go through a slow-cycling drug-tolerant state is generally considered as the first step for lineage plasticity-mediated resistance. Moreover, epigenetic and transcription factor changes and alterations of key signaling pathways, as well as crosstalk with tumor microenvironment (TME) can favor the development of phenotypic switching and TKI resistance (Fig. 2).

\section{Emergence of slow-cycling cells}

A drug-tolerant, slow-cycling state was first identified in bacteria [61]. In that scenario, a group of drug-tolerant slowcycling bacteria survive in response to antibiotic treatment, and can further convert to a proliferative state and re-established drug sensitive phenotype upon drug withdrawal [61]. Similarly, reversible drug-tolerant slow-cycling persisters were reported in NSCLC. Notably, a stepwise transition may occur in NSCLC upon TKI treatment, tumor cells first reversibly enter a slow-cycling state, then regain proliferation and ultimately become drug-resistant through further epigenetic changes or via genetic modifications (such as EGFR-T790M) [6, 15]. More recently, Sanchez-Danes et al. also discovered that in basal cell carcinoma, drug-tolerant slow-cycling residuals cells can lead to relapse upon drug withdrawal [62]. Forcing these slow-cycling cells to proliferate enhanced their sensitivity to vismodegib treatment, which leaded to their elimination [62].

LncRNAs involved in regulating cell-cycling conditions in cancer are primarily defined as p53-related lncRNAs [63]. Genome-wide profiling of p53-regulated enhancer RNAs identified $\mathrm{p} 53$-induced lincRNA-p21, LINC-PINT, TUG1, PR-lncRNA-1, PR-lncRNA-10 and LED to support cell-cycle arrest [63]. Mechanistically, lincRNAp21 bound to heterogeneous nuclear ribonucleoprotein $\mathrm{K}$ (hnRNPK) to regulate cyclin-dependent kinase inhibitor 1A (CDKN1A) is cis and arrest the cell cycle [64]. Another p53-induced lncRNA DINO was shown to interact with 553 protein and enhanced its stabilization, creating a p53 auto-amplification loop, thereby promoting damage signaling pathway and cell cycle arrest in the absence of DNA damage [65]. Moreover, alterations in cell cycle 


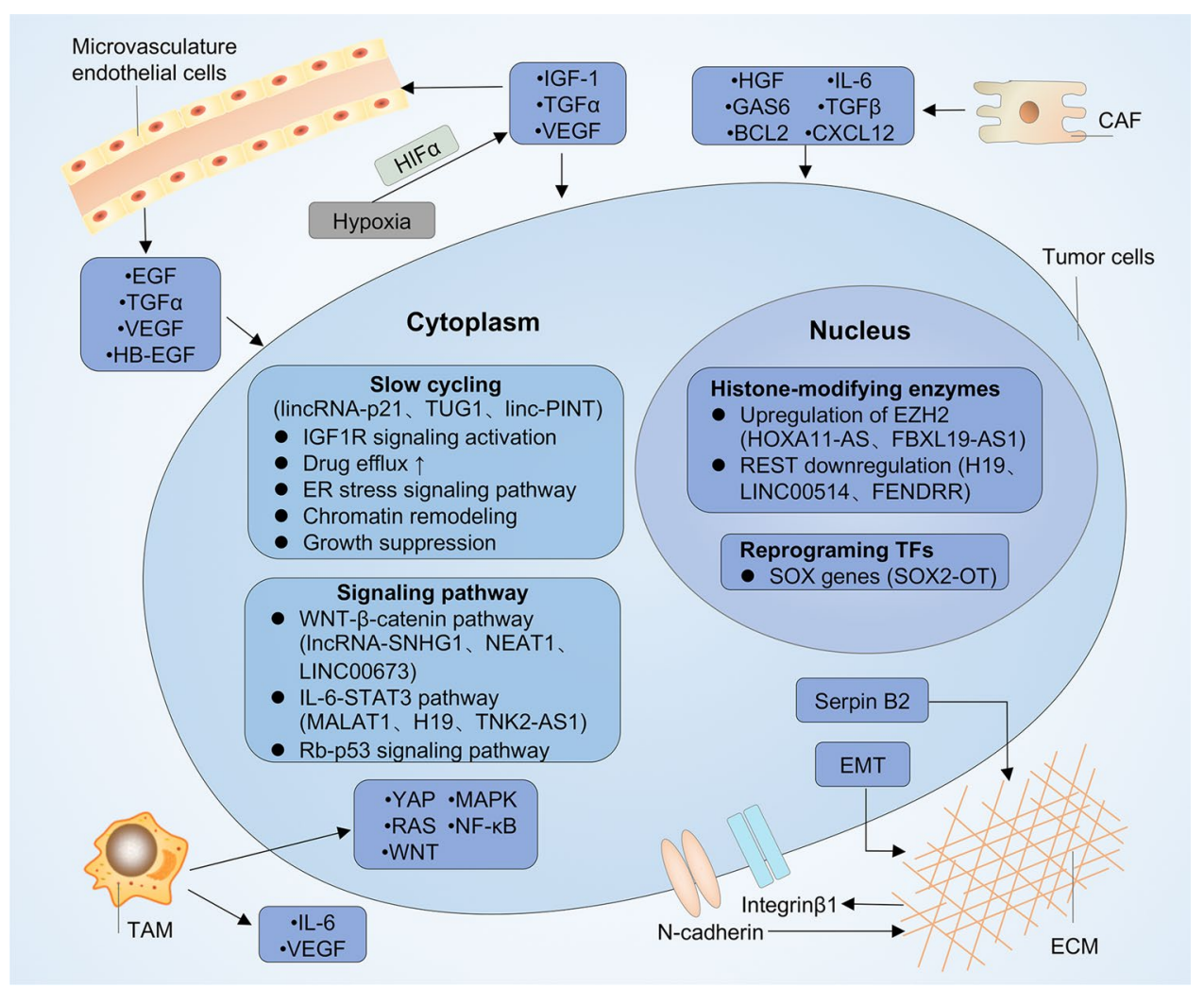

Fig. 2 Mechanisms of lncRNA-mediated lineage transition. Transcription factors (such as SOX family), histone-modifying enzymes (such as enhancer of zeste homologue 2 (EZH2) and RE1-slienicng transcription factor (REST)) regulate the reprogramming tumor cells into slow-cycling, drug-tolerant states. LncRNAs such as lincRNAp21, TUG1, linc-PINT, HOXA11-AS, SOX2-OT, FBXL19-AS1, LINC00514, FENDRR are implicated in the reprogramming process. Alterations in several key signaling pathways such as WNT- $\beta$-catenin pathway, IL-6/STAT3 pathway, NF-кB pathway and YAP pathway promote phenotypic switching upon TKI treatment. IncRNAs such as MALAT1, GHET1, SNHG1, NEAT1, H19 TNK2-AS1 are involved in these key signaling pathways. Crosstalk with the tumor microenvironment, through secretion of various cytokines from cancer-associated fibroblasts such as hepatocyte growth factor(HGF), growth arrest-specific protein 6 (GAS6), CXC-chemokine ligand 12 (CXCL12), interleukin-6 (IL-6) and transforming growth

proteins, including the silencing of cyclin dependent kinase $(\mathrm{CDK})$ inhibitor $\mathrm{p} 16$ and $\mathrm{p} 15$ are associated with resistance to EGFR TKI in NSCLC patients [66]. Several IncRNAs such as p15-AS-1 and MIR31HG can suppress $\mathrm{p} 15$ or $\mathrm{p} 16$ through heterochromatin formation [67, 68]. Moreover, MIR100HG encoded lncRNA interacts with HuR/ELAVL1 as well as several HuR-target genes (oncogenes) to suppress cell proliferation [69]. In addition, lncRNA TINCR, CASC2, MALAT1 were involved in FBXW7-mediated cell cycle arrest in various cancers [70]. Nevertheless, it remains to be elucidated whether these cell cycle-associated lncRNAs are implicated in the drug-tolerant refractory cells under the pressure of TKI. factor $\beta$ (TGF $\beta$ ); cytokines from endothelial cells such as epidermal growth factor (EGF), transforming growth factor- $\alpha$ (TGF $\alpha$ ), vascular endothelial growth factor (VEGF) and heparin-binding EGFlike growth factor (HB-EGF); Interluekin-6 (IL-6), VEGF from tumor-associated macrophage (TAM) controls tumor plasticity. The enhanced cell-cell adhesion via increased expression of integrin $\beta 1$ and $\mathrm{N}$-cadherin in tumor cells and increased extracellular matrix (ECM) stiffness via Serpin B2 can also promote tyrosine kinase inhibitors (TKI) resistance. LncRNAs involved in the M2 polarization of macrophage such as XIST and GNAS-AS1 played a part in TKI resistance. Lastly, low level of oxygen can active hypoxia-inducible factor $1 \alpha(H I F 1 \alpha)$ in tumor cells, causing autocrine signaling by secretion of TGF $\alpha$, VEGF and insulin-like growth factor (IGF-1), which promotes resistance to TKI therapy. TFs transcription factors, $C A F$ cancer-associated fibroblasts

It is important to note that most of these studies are conducted in vitro, and should, in the future, be further validated in vivo.

\section{Epigenetic modification}

The histone methyltransferase EZH2, which is the catalytic subunit of Polycomb repressive complex 2 (PRC2), is reported to promote neuroendocrine transdifferentiation in a mouse model of lung cancer [71]. Similarly, EZH2 is also a well-established feature of NEPC [31, 72]. Pharmacological or genetic inhibition of EZH2 activity in NEPC cell lines can reverse its lineage conversion and regain drug 
sensitivity [30, 31, 73] RE1-slienicng transcription factor (REST), another epigenetic regulator, is found in lung and prostate cancer during neuroendocrine conversion [74, 75]. REST suppresses gene expression generally through recruiting the co-repressors such as EZH2 [75]. Elevated levels of REST are reported to promote neuroendocrine differentiation in EGFR TKI resistance NSCLC cell lines via Notch signaling pathway [76].

Many lncRNAs have been shown to scaffold and recruit epigenetic regulator to specific genome loci. For example, IncRNAs HOXA11-AS can recruit PRC2 complex to silence miR200b [56]. On the other hand, a few lncRNAs are regulated by E2F transcription factor 1 (E2F1), which is a transcription factor that induce EZH2 expression [77]. Transcription factor-binding site (TFBS) analysis identified IncRNAs FENDRR, H19, LINC00514, LINC00617 and SSTR5-AS1 include TFBS motifs for REST and E2F, and the expression of these IncRNAs were implicated in the development of NEPC [35]. Furthermore, FBXL19-AS1/ miR-203a-3p axis was found to enhance E2F1 and ZEB1 in lung adenocarcinomas (LUAD) cells [78]. Therefore, lncRNAs are important players in scaffolding EZH2-dependent gene silencing and subsequent regulate EZH2-mediated phenotypic switching.

\section{SOX family members}

Several lineage-specific transcription factors are involved in lineage plasticity and drug escape both in NSCLC and prostate cancer. The SOX family is important in regulating cell fate decisions and is implicated in phenotypic conversion in various cancer models [79]. For instance, the expression of SOX2 was increased in TP53 and RB1-deficient GEMMs and xenograft models of LUAD and prostate cancers [30, 31]. Moreover, the neural lineage-specific factor BRN2, which is specifically expressed in SCLC and NEPC tumors, mediates SOX2 expression and is key for neuroendocrine transformation [80, 81]. Furthermore, insulinoma-associated-1 (INSM1), which encodes a zinc-finger transcription factor, has recently emerged as a specific neuroendocrine transcription factor and a sensitive biomarker for neuroendocrine tumors [82].

LncRNA SOX2 overlapping transcript (SOX2-OT) are functionally assumed to be associated with neuronal like differentiation and carcinogenesis [83, 84]. Concordant expression of SOX2 and SOX2-OT is found in lung and breast cancer [83]. Notably, SOX2-OT can generate six transcript variants in different cancer models [85, 86], and have been proposed to play a role in regulating the expression of SOX2 [84, 85]. Collectively, SOX reprogramming factors, together with other lineage-associated transcription factors, are key for cellular plasticity in TKI resistant NSCLC cells. LncRNA-SOX2-OT, as SOX2 overlapping transcript also makes contribution for promoting the transition toward neural crest state in NSCLC.

\section{Key signaling pathways}

Several signaling pathways play a part in phenotypic switching upon TKI treatment. The activation of WNT- $\beta$-catenin pathway is reported to promote neuroendocrine differentiation in various cancer models [87]. Meder et al. discovered NOTCH-Achaete-scure complex homolog 1(ASCL)-WNT signaling pathway could inactivate RB by phosphorylation and, therefore, promote neuroendocrine differentiation in NSCLC $[88,89]$. Moreover, achaete-scute homolog 1 (ASH1) also acts as a positive regulator of $\mathrm{WNT} / \beta$-catenin pathway, transforming NSCLC into a SCLC phenotype with neuroendocrine features both in vitro and in vivo models [90]. A number of lncRNAs have been found to active WNT/ $\beta$-catenin to induce EMT and therapy resistance in NSCLC [91-93]. For instance, lncRNA-SNHG1 can sequester miR $140-5 p$ from binding WNT to active WNT/ $\beta$-catenin signaling in NSCLC [92]. LINC00673 functions as a modular scaffold to strengthen the interaction between DDX3 and CK1 $1 \varepsilon$, induces phosphorylation of Dvl and, therefore, promote the nuclear accumulation of $\beta$-catenin and the activation of WNT/ $\beta$-catenin signaling pathway in LUAD [93]. Furthermore, the expressions of lncRNA-NEAT1, FOXO2AS1 were positively associated with WNT/ $\beta$-catenin signaling in NSCLC tissues. Knockdown of NEAT1 or FOXO2AS1 inhibited WNT/ $\beta$-catenin signaling pathway activity $[91,94,95]$.

IL-6-STAT3 axis is also activated upon EGFR TKI treatment and can promote neuroendocrine differentiation in NSCLC [96]. LncRNAs such as MALAT1 and H19 are reported to, respectively, sponge miR-124, miR-17 and miR29b-3p, subsequently activated STAT3 and promote therapy resistance [97-99]. In addition, Wang et al. showed IncRNA TNK2-AS1 was significantly upregulated in NSCLC and associated with poor survival. Mechanistically, TNK2-AS1 could interact with STAT3 to enhance its protein stability, on the other hand, STAT3 also triggers the transcription of TNK2-AS1. Thus, the positive feedback loop between TNK2-AS1 and STAT3 augmented STAT3 signaling pathway in NSCLC [100].

\section{The tumor microenvironment}

The tumor microenvironment (TME) is a multicellular system with dynamic tumor-stromal component interactions $[101,102]$. Altogether, the various stromal components such as fibroblasts, endothelial cells and infiltrating immune cells influence the response to TKI therapy.

It is well established that cancer-associated fibroblasts (CAFs) can induce EMT and TKI resistance in NSCLC 
cells in vitro $[103,104]$. The secretion of soluble factors such as hepatocyte growth factor (HGF) promoted MET or ERK activation and subsequent EGFR TKI resistance in NSCLC cells $[105,106]$. CAFs can also derive the AXL ligand growth arrest-specific protein 6 (GAS6) and enhance the expression of anti-apoptotic gene BCL2, leading to TKI resistance [26, 107].

The extracellular matrix (ECM) also interacts with NSCLC cells to promote drug tolerance. A study in 3D lung cancer cell models revealed that ECM-induced ERK and PI3K/AKT signaling lead to an EGFR TKI tolerant dormant state [108]. Low levels of SerpinB2 (a serine protease inhibitor that increase ECM stiffness), is negatively associated with gefitinib resistance in vitro. And treatment with a SerpinB2-inducing agent reversed the drug-tolerant state [108]. Moreover, Elevated levels of $\mathrm{N}$-cadherin and integrin $\beta$ could promote tumor cells adhesion to ECM, thereby, promoting EGFR TKI resistance [109].

Tumor-associated macrophages (TAMs) are important infiltrating immune cells with crucial role in the development of TKI resistance [110]. Patients with increased TAM infiltration within the TME had poor outcomes [111]. Computational modelling of RNA expression in a mouse model of NSCLC revealed TAMs-secreted factors can activate various signaling pathways related to EGFR TKI resistance, including the MAPK, YAP, NF- $\mathrm{KB}, \mathrm{PI} 3 \mathrm{~K}$, WNT and RAS pathways [112]. Furthermore, macrophage could promote EMT through the IL-6-mediated COX2/PGE $/ \beta$-catenin signaling pathway [113]. Notably, a few lncRNAs such as GNAS-AS1 and XIST are reported to promote macrophage M2 polarization in NSCLC and, therefore, play a part in TAM-induced drug tolerant $[114,115]$.

Finally, hypoxia and the density and distribution of vasculature are closely associated with EGFR TKI resistance. Hypoxia-inducible factor $1 \alpha(\mathrm{HIF} 1 \alpha)$ promotes TKI resistance in a TGF $\alpha$-dependent manner and increases cancer stem phenotype via IGF1R activation [116, 117]. In addition, the secretion of vascular endothelial growth factor (VEGF) by endothelial cells under hypoxia promotes angiogenesis and drug resistance [118]. Additionally, the expression of immune checkpoint programmed cell death 1 ligand 1 (PDL1) are upregulated in some EGFR-mutated or ALK-rearranged NSCLC patients. A preliminary study has found the combination of PDL1 nanobody and gefitinib displayed effectiveness of reversing the gefitinib resistance in NSCLC [119]. However, the extent of TME contributes to TKI resistance and the involvement of IncRNAs in TMEmediated resistance warrants further investigation, particularly as novel therapies that target immune and stromal cells continue to emerge. The emerging challenge is to clarify whether there is potential for therapeutic synergy between immunotherapy and targeted therapy in preventing lineage plasticity and TKI resistance.

\section{Targeting strategies for lineage plasticity}

\section{Targeting epigenetic regulators}

Since certain epigenetic alterations are correlated with slow-cycling drug-tolerant cells, targeting the potential epigenetic regulators serves as an important way to ameliorate lineage plasticity. Notably, preventing phenotypic switching by targeting HDAC or histone demethylases KDM5A/B and KDM6A/B have promising results in earlyphase studies [120]. In NSCLC, trimethylation of lysine 9 on histone (H3K9me3) represses long-interspersed repeat elements 1 (LINE-1), thus inhibiting the expression of interferon and antiviral-activated genes to promote EGFR TKI-tolerant cell survival [121, 122]. HDAC inhibitor trichostatin A or entinostat counterbalanced the drug-tolerant cells via suppressing LINE [121]. Early-phase studies of detecting HDAC inhibitors in combination with EGFR TKI are ongoing. Inhibiting demethylases KDM6 with GSK-J4 suppressed residual persister cells in glioblastoma [123, 124]. (Table 2).

EZH2 is another druggable epigenetic regulator as mentioned previously [72]. Several phase I and phase II clinical trials are ongoing to inhibit EZH2 in lymphomas and multiple solid tumors $[125,126]$. In a mouse model of human LUAD, using an open-source EZH2 inhibitor JQEZ5, Zhang et al. have established efficient antitumor effects [127, 128]. Another study has found that EZH2 inhibitor GSK343 synergy with gefitinib in NSCLC cells [129]. However, EZH2 inhibitor GSK2816126 failed in another early phase II trial in patients with similar indications [14]. Assessment of other epigenetic regulators, such as REST, are also ongoing. In addition, the dual HDAC and 3-hydroxy-3-methylgutaryl coenzyme A reductase inhibitor, JMF3086, which regulate the post-translational regulation of E-cadherin, can restore the sensitivity to first and third-generation EGFR-TKI in NSCLC [130]. (Fig. 3).

Numerous mechanistic studies support the hypothesis that targeting epigenetic regulators can synergize with TKI agents and reverse lineage plasticity in preclinical models. Nevertheless, the efficacy of epi-drugs tested in clinical trials to date has been disappointing. Overall, the epigenetic modulators exert broadening effects on cell biology and systemic physiology. Inhibitors targeting epigenetic regulators might lead to the dysregulation of cell biology $[131,132]$. Therefore, novel agents are needed to target lineage plasticity more specifically. LncRNAs are excellent candidates in this respect. Several features of lncRNAs render their potential therapeutic targets in lineage plasticity-mediated TKI resistance. First, the expression of lncRNAs show strong conservation of tissue specificity [133]. Interestingly, many lncRNAs are patient and 
Table 2 Selected clinical NSCLC trials of targets and compound targeting lineage plasticity

\begin{tabular}{|c|c|c|c|c|c|}
\hline Drug regimen & Phase & Identification & Results & Chilicaltrials.gov identifier & Refs \\
\hline \multicolumn{6}{|l|}{ HDAC inhibitor } \\
\hline Vorinostat + gefitinib & $\mathrm{I} / \mathrm{II}$ & $\begin{array}{l}\text { Relapsed/refractory } \\
\text { advanced NSCLC }\end{array}$ & No improvement in PFS & NCT01027676 & {$[120]$} \\
\hline Vorinostat + erlotinib & $\mathrm{I} / \mathrm{II}$ & $\begin{array}{l}\text { Relapsed EGFR-mutant } \\
\text { NSCLC }\end{array}$ & $\begin{array}{l}\text { No improvement in erlo- } \\
\text { tinib-resistant population }\end{array}$ & NCT00503971 & {$[120]$} \\
\hline Belinostat + Erlotinib & I & Molecularly unselected & Results pending & NCT01027676 & {$[120]$} \\
\hline SNDX-275 + Erlotinib & II & Progression on erlotinib & Results pending & NCT00750698 & [120] \\
\hline \multicolumn{6}{|l|}{ KDM5 and KDM6 } \\
\hline $\begin{array}{l}\text { YUKA1, CPI-455 } \\
\text { (KDM5A specific), } \\
\text { KDOAM-25 (KDM5A-D } \\
\text { specific) + gefitinib }\end{array}$ & Preclinical & EGFR-mutant NSCLC & $\begin{array}{l}\text { YUKA1 in combination with } \\
\text { gefitinib prevents drug } \\
\text { tolerance in EFGR-mutant } \\
\text { NSCLC }\end{array}$ & & {$[123,124]$} \\
\hline \multicolumn{6}{|l|}{ CDK7/12 } \\
\hline SY-1365 & I & Advanced solid tumors & Ongoing & NCT03134638 & \\
\hline \multicolumn{6}{|l|}{ AXL inhibitor } \\
\hline BGB324 + erlotinib & II & $\begin{array}{l}\text { Molecularly unselected } \\
\text { NSCLC }\end{array}$ & First efficacy end point met & NCT02424617 & [141] \\
\hline SGI-7079+erlotinib & Preclinical & $\begin{array}{l}\text { Molecularly unselected } \\
\text { NSCLC }\end{array}$ & $\begin{array}{l}\text { Enhanced sensitivity of } \\
\text { mesenchymal-like NSCLC } \\
\text { cells to erlotinib }\end{array}$ & & {$[25]$} \\
\hline TP-0903 & $\mathrm{Ia} / \mathrm{Ib}$ & Advanced solid tumors & Ongoing & NCT02729298 & \\
\hline \multicolumn{6}{|l|}{ E-cadherin } \\
\hline JMF3086 & Preclinical & $\begin{array}{l}\text { Molecularly unselected } \\
\text { NSCLC }\end{array}$ & $\begin{array}{l}\text { Restore sensitivity to EGFR- } \\
\text { TKI }\end{array}$ & & {$[130]$} \\
\hline \multicolumn{6}{|l|}{ EZH2 inhibitor } \\
\hline JQEZ5 & Preclinical & $\begin{array}{l}\text { EGFR or BRG1-mutant } \\
\text { NSCLC }\end{array}$ & $\begin{array}{l}\text { Decreased tumor burden } \\
\text { in GEMM and human } \\
\text { NSCLC models }\end{array}$ & & {$[127,128]$} \\
\hline GSK343 + gefitinib & Preclinical & NSCLC & Inhibited cell viability & & [129] \\
\hline
\end{tabular}

NSCLC non-small-cell lung cancer, EGFR epidermal growth factor receptor, $H D A C$ histone deacetylase, $P F S$ progression-free survival, $K D M$ histone demethylase, $R X R$ retinoid $\mathrm{X}$ receptor, $E Z H 2$ zeste homologue 2, IL-6 interleukin-6, $A X L$ receptor tyrosine kinase, $T K I$ tyrosine kinase inhibitors

tumor specific [134]. The exclusive expression pattern of lncRNAs in specific types of tissues or cells provides an opportunity for specific regulation by lncRNA-targeting therapeutics [133, 135]. Second, chromatin modification represents an important mechanism for IncRNA, thus targeting the interaction of lncRNAs with epigenetic factors such as EZH2 can be envisioned. Third, many nuclear lncRNAs regulate neighboring gene expression in cis, thus locus-specific regulation can be achieved through lncRNA manipulation. However, the development of lncRNA therapeutics is the still in its infancy. Traditional RNAi has proven generally ineffective for lncRNA, due to their unique localization and expression [136]. Currently, antisense oligonucleotides (ASOs) and CRISPR-Cas9 are considered as promising approaches to target lncRNAs [137, 138]. Furthermore, we anticipate that future pooled CRISPR screening will be implemented to identify lineage plasticity-related lncRNAs. Nevertheless, we are beginning to understand the roles of IncRNAs in lineage plasticity. Targeting lineage plasticity associated lncRNAs in combination with TKI treatment has not been reported yet. Further translation research and clinical trials are needed.

\section{New cell fate management}

In addition to targeting epigenetic regulators involving in lineage plasticity, it is also appealing to target the emerging drug-tolerant cell identity. There are ongoing efforts to evaluate whether NSCLC that have undergone neuroendocrine differentiation share similar treatment schedules with de novo SCLC. Notably, transformed SCLC presented sensitivity to palatium-etoposide, which makes them more similar to de novo SCLC [139]. However, it is important to note that a contrasting result came from another retrospective study, in which transformed SCLC patients still displayed higher responsive to taxanes than de novo SCLC but failed response to checkpoint inhibitor 


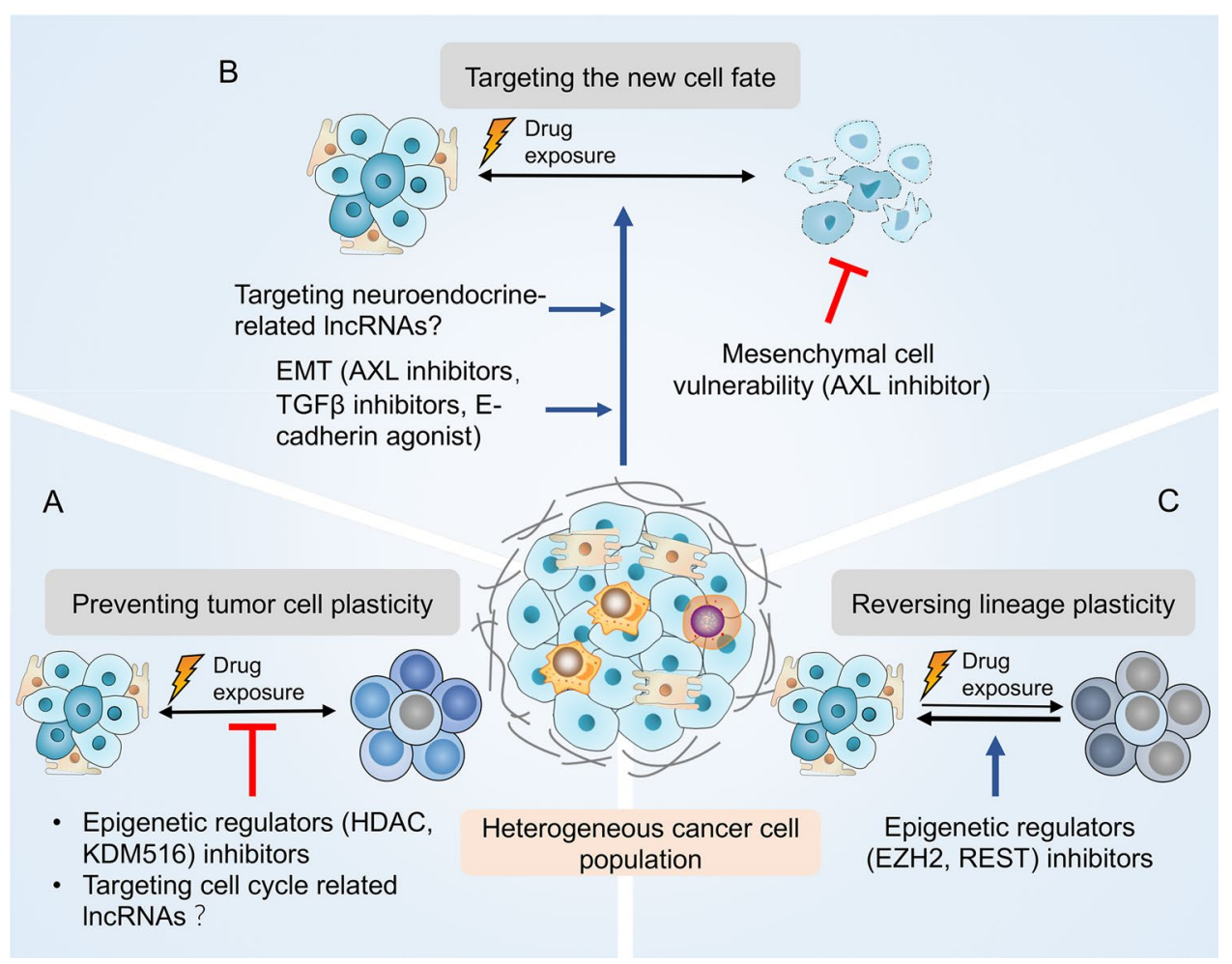

Fig. 3 Principal strategies to target lineage plasticity in NSCLC. Three general approaches that target lineage plasticity are listed here: preventing lineage plasticity, targeting the emerging new cell identity and reversing the lineage plasticity. a Preventing lineage plasticity may prolong the clinical response to TKI treatment. Crucial signals and molecules that regulate the survival of slow-cycling cell, for instance, chromatin landscape remodeling modulators and cell cyclerelated lncRNAs can be targeted to block tumor cellular plasticity. b The emerging drug-tolerant cell identity such as SCLC and epithe-

therapy [19]. Therefore, treatment regimens on transformed SCLC need to be cautiously evaluated and await further functional investigation. Interestingly, our previous study demonstrated certain non-coding RNA could facilitate the therapeutic effects of EGFR-TKI in NSCLC [140]. Our unpublished data also showed that a few lncRNAs are crucial for the transformation from NSCLC to SCLC in response to TKI treatment and could be targeted to prevent lineage plasticity. Therefore, lncRNAs involving in the histological transformation will be worthwhile areas for further investigation.

EMT represents an important process determining new cell fate of cancer. The correlation between the expression of EMT signature and receptor tyrosine kinase AXL in NSCLC indicates that AXL may represent a novel target [25]. Notably, combination of AXL inhibitor SGI-7079 with EGFR TKI erlotinib increased the sensitivity of mesenchymal-like tumor cells to erlotinib in a mouse xenograft NSCLC model [25]. Preliminary findings also suggest that BGB324, the first AXL-specific-molecule inhibitor approved for clinic, lial-mesenchymal transition (EMT) feature can be eliminated through targeting neuroendocrine-related lncRNAs, AXL, TGF $\beta$ and E-cadherin. c Lineage plasticity can be reverted to resensitize NSCLC to TKI. Epigenetic regulators, such as enhancer of zeste homologue 2 (EZH2) and RE1-silencing transcription factors (REST), can be targeted for reversing lineage plasticity. NSCLC non-small-cell lung cancer, $S C L C$ small-cell lung cancer, $T K I$ tyrosine kinase inhibitor, $K D M$ histone demethylase, $H D A C$ histone deacetylase, $T G F \beta$ transforming growth factor- $\beta$

can be safely administered, resulting in disease stabilization in a group of NSCLC patients [141].

\section{Conclusion}

Along with genetic alterations, lineage plasticity has recently considered to play a key part in the development of TKI resistance in NSCLC. Despite the functions of lncRNAs in cancer have been extensively studied in the past few years, we are beginning to understand the implications of lncRNA in TKI resistance in NSCLC, particularly in regulating lineage plasticity-mediated drug escape. A better understanding of the deregulated lncRNA involved in lineage plasticity will shed light on the complexity of the molecular alterations underlying TKI resistance. Recently, CRISPR-based screening has successfully identified many cancer-promoting lncRNAs. The simplicity, low cost and flexibility of pooled CRISPR screening brings transcriptome-wide screens within reach of the average molecular oncology laboratory. 
We anticipate that future pooled CRISPR screening will be implemented to identify lineage plasticity-related lncRNAs. The current strategies to target lineage plasticity mainly include targeting the epigenetic and transcriptional alterations. However, there remains many challenges ahead to better understand the process. First, the molecular determinants and biomarker for tumor cell phenotypic plasticity upon TKI treatment needs to be better understood. Second, the heterogeneity should be taken into account when targeting the residual tumor cells. Finally, further investigations such as CRISPR screening are required to discover lineage plasticity-related lncRNAs, and use lncRNAs as novel diagnosis and treatment modalities. Overcoming the obstacles will enable us to implement personalized medicine in the treatment of TKI resistance in NSCLC patients.

Author contributions TYL wrote the manuscript. CC H prepared all the figures and tables. PQF, HYZ and SW W were involved in the revising of the manuscript, ZFM, QLZ and WJX contributed to the manuscript preparation. RY, JW and LX participated in the design of the manuscript and the revision. All authors read and approved the final manuscript.

Funding This work was supported by the National Natural Science Foundation of China $(81802277,81872378,81802907)$ and China Postdoctoral Science Foundation (2018M642198), Project of Jiangsu Provincial Medical Talent (ZDRCA2016033).

Availability of data and materials All data generated during this study are included in this published article.

\section{Compliance with ethical standards}

conflict of interest The authors declare no competing interests.

Consent for publication All authors reviewed and approved the manuscript.

Open Access This article is licensed under a Creative Commons Attribution 4.0 International License, which permits use, sharing, adaptation, distribution and reproduction in any medium or format, as long as you give appropriate credit to the original author(s) and the source, provide a link to the Creative Commons licence, and indicate if changes were made. The images or other third party material in this article are included in the article's Creative Commons licence, unless indicated otherwise in a credit line to the material. If material is not included in the article's Creative Commons licence and your intended use is not permitted by statutory regulation or exceeds the permitted use, you will need to obtain permission directly from the copyright holder. To view a copy of this licence, visit http://creativecommons.org/licenses/by/4.0/.

\section{References}

1. Hanahan D (2014) Rethinking the war on cancer. Lancet 383(9916):558-563. https://doi.org/10.1016/S0140 $-6736(13) 62226-6$
2. Altorki NK, Markowitz GJ, Gao D, Port JL, Saxena A, Stiles B, McGraw T, Mittal V (2019) The lung microenvironment: an important regulator of tumour growth and metastasis. Nat Rev Cancer 19(1):9-31. https://doi.org/10.1038/s41568-018-0081-9

3. Rotow J, Bivona TG (2017) Understanding and targeting resistance mechanisms in NSCLC. Nat Rev Cancer 17(11):637-658. https://doi.org/10.1038/nrc.2017.84

4. Mayekar MK, Bivona TG (2017) Current landscape of targeted therapy in lung cancer. Clin Pharmacol Ther 102(5):757-764. https://doi.org/10.1002/cpt.810

5. Roesch A (2015) Tumor heterogeneity and plasticity as elusive drivers for resistance to MAPK pathway inhibition in melanoma. Oncogene 34(23):2951-2957. https://doi.org/10.1038/ onc.2014.249

6. Hata AN, Niederst MJ, Archibald HL, Gomez-Caraballo M, Siddiqui FM, Mulvey HE, Maruvka YE, Ji F, Bhang HE, Krishnamurthy Radhakrishna V, Siravegna G, Hu H, Raoof S, Lockerman E, Kalsy A, Lee D, Keating CL, Ruddy DA, Damon LJ, Crystal AS, Costa C, Piotrowska Z, Bardelli A, Iafrate AJ, Sadreyev RI, Stegmeier F, Getz G, Sequist LV, Faber AC, Engelman JA (2016) Tumor cells can follow distinct evolutionary paths to become resistant to epidermal growth factor receptor inhibition. Nat Med 22(3):262-269. https://doi.org/10.1038/nm.4040

7. Quintanal-Villalonga A, Chan JM, Yu HA, Pe'er D, Sawyers CL, Sen T, Rudin CM (2020) Lineage plasticity in cancer: a shared pathway of therapeutic resistance. Nat Rev Clin Oncol. https:// doi.org/10.1038/s41571-020-0340-z

8. Barkley D, Yanai I (2019) Plasticity and clonality of cancer cell states. Trends Cancer 5(11):655-656. https://doi.org/10.1016/j. trecan.2019.09.002

9. Ramirez M, Rajaram S, Steininger RJ, Osipchuk D, Roth MA, Morinishi LS, Evans L, Ji W, Hsu CH, Thurley K, Wei S, Zhou A, Koduru PR, Posner BA, Wu LF, Altschuler SJ (2016) Diverse drug-resistance mechanisms can emerge from drug-tolerant cancer persister cells. Nat Commun 7:10690. https://doi. org/10.1038/ncomms 10690

10. Wang Z, Yang B, Zhang M, Guo W, Wu Z, Wang Y, Jia L, Li S, Cancer Genome Atlas Research N, Xie W, Yang D (2018) lncRNA Epigenetic landscape analysis identifies EPIC1 as an oncogenic lncRNA that interacts with MYC and promotes cellcycle progression in cancer. Cancer Cell 33(4):706-720. https:// doi.org/10.1016/j.ccell.2018.03.006 ((e709))

11. Lee JT (2012) Epigenetic regulation by long noncoding RNAs. Science 338(6113):1435-1439. https://doi.org/10.1126/scien ce. 1231776

12. Sequist LV, Waltman BA, Dias-Santagata D, Digumarthy S, Turke AB, Fidias P, Bergethon K, Shaw AT, Gettinger S, Cosper AK, Akhavanfard S, Heist RS, Temel J, Christensen JG, Wain JC, Lynch TJ, Vernovsky K, Mark EJ, Lanuti M, Iafrate AJ, MinoKenudson M, Engelman JA (2011) Genotypic and histological evolution of lung cancers acquiring resistance to EGFR inhibitors. Sci Transl Med 3(75):75ra26. https://doi.org/10.1126/scitr anslmed.3002003

13. Yuan S, Norgard RJ, Stanger BZ (2019) Cellular plasticity in cancer. Cancer Discov 9(7):837-851. https://doi.org/10.1158/21598290.CD-19-0015

14. Boumahdi S, de Sauvage FJ (2019) The great escape: tumour cell plasticity in resistance to targeted therapy. Nat Rev Drug Discov. https://doi.org/10.1038/s41573-019-0044-1

15. Sharma SV, Lee DY, Li B, Quinlan MP, Takahashi F, Maheswaran S, McDermott U, Azizian N, Zou L, Fischbach MA, Wong KK, Brandstetter K, Wittner B, Ramaswamy S, Classon M, Settleman J (2010) A chromatin-mediated reversible drugtolerant state in cancer cell subpopulations. Cell 141(1):69-80. https://doi.org/10.1016/j.cell.2010.02.027 
16. Menon DR, Das S, Krepler C, Vultur A, Rinner B, Schauer S, Kashofer K, Wagner K, Zhang G, Rad EB, Haass NK, Soyer HP, Gabrielli B, Somasundaram R, Hoefler G, Herlyn M, Schaider $\mathrm{H}$ (2015) A stress-induced early innate response causes multidrug tolerance in melanoma. Oncogene 34(34):4545. https://doi. org/10.1038/onc.2014.432

17. Oser MG, Niederst MJ, Sequist LV, Engelman JA (2015) Transformation from non-small-cell lung cancer to small-cell lung cancer: molecular drivers and cells of origin. Lancet Oncol 16(4):e165-172. https://doi.org/10.1016/S1470-2045(14)71180 $-5$

18. Lee JK, Lee J, Kim S, Kim S, Youk J, Park S, An Y, Keam B, Kim DW, Heo DS, Kim YT, Kim JS, Kim SH, Lee JS, Lee SH, Park K, Ku JL, Jeon YK, Chung DH, Park PJ, Kim J, Kim TM, Ju YS (2017) Clonal history and genetic predictors of transformation into small-cell carcinomas from lung adenocarcinomas. J Clin Oncol 35(26):3065-3074. https://doi.org/10.1200/ JCO.2016.71.9096

19. Marcoux N, Gettinger SN, O’Kane G, Arbour KC, Neal JW, Husain H, Evans TL, Brahmer JR, Muzikansky A, Bonomi PD, Del Prete S, Wurtz A, Farago AF, Dias-Santagata D, MinoKenudson M, Reckamp KL, Yu HA, Wakelee HA, Shepherd FA, Piotrowska Z, Sequist LV (2019) EGFR-Mutant adenocarcinomas that transform to small-cell lung cancer and other neuroendocrine carcinomas: clinical outcomes. J Clin Oncol 37(4):278-285. https://doi.org/10.1200/JCO.18.01585

20. Niederst MJ, Sequist LV, Poirier JT, Mermel CH, Lockerman EL, Garcia AR, Katayama R, Costa C, Ross KN, Moran T, Howe E, Fulton LE, Mulvey HE, Bernardo LA, Mohamoud F, Miyoshi N, VanderLaan PA, Costa DB, Janne PA, Borger DR, Ramaswamy S, Shioda T, Iafrate AJ, Getz G, Rudin CM, Mino-Kenudson M, Engelman JA (2015) RB loss in resistant EGFR mutant lung adenocarcinomas that transform to small-cell lung cancer. Nat Commun 6:6377. https://doi.org/10.1038/ncomms7377

21. Tata PR, Rajagopal J (2016) Cellular plasticity: 1712 to the present day. Curr Opin Cell Biol 43:46-54. https://doi.org/10.1016/j. ceb.2016.07.005

22. Davies AH, Beltran H, Zoubeidi A (2018) Cellular plasticity and the neuroendocrine phenotype in prostate cancer. Nat Rev Urol 15(5):271-286. https://doi.org/10.1038/nrurol.2018.22

23. Zakowski MF, Ladanyi M, Kris MG, Memorial Sloan-Kettering Cancer Center Lung Cancer OncoGenome G (2006) EGFR mutations in small-cell lung cancers in patients who have never smoked. N Engl J Med 355(2):213-215. https://doi.org/10.1056/ NEJMc053610

24. Gower A, Hsu WH, Hsu ST, Wang Y, Giaccone G (2016) EMT is associated with, but does not drive resistance to ALK inhibitors among EML4-ALK non-small cell lung cancer. Mol Oncol 10(4):601-609. https://doi.org/10.1016/j.molonc.2015.11.007

25. Zhang Z, Lee JC, Lin L, Olivas V, Au V, LaFramboise T, AbdelRahman M, Wang X, Levine AD, Rho JK, Choi YJ, Choi CM, Kim SW, Jang SJ, Park YS, Kim WS, Lee DH, Lee JS, Miller VA, Arcila M, Ladanyi M, Moonsamy P, Sawyers C, Boggon TJ, Ma PC, Costa C, Taron M, Rosell R, Halmos B, Bivona TG (2012) Activation of the AXL kinase causes resistance to EGFRtargeted therapy in lung cancer. Nat Genet 44(8):852-860. https ://doi.org/10.1038/ng.2330

26. Byers LA, Diao L, Wang J, Saintigny P, Girard L, Peyton M, Shen L, Fan Y, Giri U, Tumula PK, Nilsson MB, Gudikote J, Tran H, Cardnell RJ, Bearss DJ, Warner SL, Foulks JM, Kanner SB, Gandhi V, Krett N, Rosen ST, Kim ES, Herbst RS, Blumenschein GR, Lee JJ, Lippman SM, Ang KK, Mills GB, Hong WK, Weinstein JN, Wistuba II, Coombes KR, Minna JD, Heymach JV (2013) An epithelial-mesenchymal transition gene signature predicts resistance to EGFR and PI3K inhibitors and identifies Axl as a therapeutic target for overcoming EGFR inhibitor resistance.
Clin Cancer Res 19(1):279-290. https://doi.org/10.1158/10780432.CCR-12-1558

27. Chung JH, Rho JK, Xu X, Lee JS, Yoon HI, Lee CT, Choi YJ, Kim HR, Kim CH, Lee JC (2011) Clinical and molecular evidences of epithelial to mesenchymal transition in acquired resistance to EGFR-TKIs. Lung Cancer 73(2):176-182. https://doi. org/10.1016/j.lungcan.2010.11.011

28. Wu WS, Heinrichs S, Xu D, Garrison SP, Zambetti GP, Adams JM, Look AT (2005) Slug antagonizes p53-mediated apoptosis of hematopoietic progenitors by repressing puma. Cell 123(4):641653. https://doi.org/10.1016/j.cell.2005.09.029

29. Saxena M, Stephens MA, Pathak H, Rangarajan A (2011) Transcription factors that mediate epithelial-mesenchymal transition lead to multidrug resistance by upregulating $\mathrm{ABC}$ transporters. Cell Death Dis 2:e179. https://doi.org/10.1038/cddis.2011.61

30. Mu P, Zhang Z, Benelli M, Karthaus WR, Hoover E, Chen CC, Wongvipat J, Ku SY, Gao D, Cao Z, Shah N, Adams EJ, Abida W, Watson PA, Prandi D, Huang CH, de Stanchina E, Lowe SW, Ellis L, Beltran H, Rubin MA, Goodrich DW, Demichelis F, Sawyers CL (2017) SOX2 promotes lineage plasticity and antiandrogen resistance in TP53- and RB1-deficient prostate cancer. Science 355(6320):84-88. https://doi.org/10.1126/ science.aah4307

31. Ku SY, Rosario S, Wang Y, Mu P, Seshadri M, Goodrich ZW, Goodrich MM, Labbe DP, Gomez EC, Wang J, Long HW, Xu B, Brown M, Loda M, Sawyers CL, Ellis L, Goodrich DW (2017) Rb1 and Trp53 cooperate to suppress prostate cancer lineage plasticity, metastasis, and antiandrogen resistance. Science 355(6320):78-83. https://doi.org/10.1126/science.aah41 99

32. Niederst MJ, Engelman JA (2013) Bypass mechanisms of resistance to receptor tyrosine kinase inhibition in lung cancer. Sci Signal 6(294):re6. https://doi.org/10.1126/scisignal.2004652

33. Li M, Izpisua Belmonte JC (2015) Roles for noncoding RNAs in cell-fate determination and regeneration. Nat Struct Mol Biol 22(1):2-4. https://doi.org/10.1038/nsmb.2946

34. Crea F, Venalainen E, Ci X, Cheng H, Pikor L, Parolia A, Xue H, Nur Saidy NR, Lin D, Lam W, Collins C, Wang Y (2016) The role of epigenetics and long noncoding RNA MIAT in neuroendocrine prostate cancer. Epigenomics 8(5):721-731. https://doi. org/10.2217/epi.16.6

35. Ramnarine VR, Alshalalfa M, Mo F, Nabavi N, Erho N, Takhar M, Shukin R, Brahmbhatt S, Gawronski A, Kobelev M, Nouri M, Lin D, Tsai H, Lotan TL, Karnes RJ, Rubin MA, Zoubeidi A, Gleave ME, Sahinalp C, Wyatt AW, Volik SV, Beltran H, Davicioni E, Wang Y, Collins CC (2018) The long noncoding RNA landscape of neuroendocrine prostate cancer and its clinical implications. Gigascience. https://doi.org/10.1093/gigascience/ giy050

36. Shibue T, Weinberg RA (2017) EMT, CSCs, and drug resistance: the mechanistic link and clinical implications. Nat Rev Clin Oncol 14(10):611-629. https://doi.org/10.1038/nrcli nonc. 2017.44

37. Gugnoni M, Ciarrocchi A (2019) Long noncoding RNA and epithelial mesenchymal transition in cancer. Int J Mol Sci. https:// doi.org/10.3390/ijms20081924

38. Grelet S, Link LA, Howley B, Obellianne C, Palanisamy V, Gangaraju VK, Diehl JA, Howe PH (2017) A regulated PNUTS mRNA to lncRNA splice switch mediates EMT and tumour progression. Nat Cell Biol 19(9):1105-1115. https://doi. org/10.1038/ncb3595

39. Lu W, Zhang H, Niu Y, Wu Y, Sun W, Li H, Kong J, Ding K, Shen HM, Wu H, Xia D, Wu Y (2017) Long non-coding RNA linc00673 regulated non-small cell lung cancer proliferation, migration, invasion and epithelial mesenchymal transition 
by sponging miR-150-5p. Mol Cancer 16(1):118. https://doi. org/10.1186/s12943-017-0685-9

40. Ge X, Li GY, Jiang L, Jia L, Zhang Z, Li X, Wang R, Zhou M, Zhou Y, Zeng Z, Xiang J, Li Z (2019) Long noncoding RNA CAR10 promotes lung adenocarcinoma metastasis via miR203/30/SNAI axis. Oncogene 38(16):3061-3076. https://doi. org/10.1038/s41388-018-0645-X

41. Peng W, He D, Shan B, Wang J, Shi W, Zhao W, Peng Z, Luo Q, Duan M, Li B, Cheng Y, Dong Y, Tang F, Zhang C, Duan C (2019) LINC81507 act as a competing endogenous RNA of miR-199b-5p to facilitate NSCLC proliferation and metastasis via regulating the CAV1/STAT3 pathway. Cell Death Dis 10(7):533. https://doi.org/10.1038/s41419-019-1740-9

42. Jia Y, Duan Y, Liu T, Wang X, Lv W, Wang M, Wang J, Liu L (2019) LncRNA TTN-AS1 promotes migration, invasion, and epithelial mesenchymal transition of lung adenocarcinoma via sponging miR-142-5p to regulate CDK5. Cell Death Dis 10(8):573. https://doi.org/10.1038/s41419-019-1811-y

43. Zhang Q, Li X, Li X, Li X, Chen Z (2018) LncRNA H19 promotes epithelial-mesenchymal transition (EMT) by targeting miR-484 in human lung cancer cells. J Cell Biochem 119(6):4447-4457. https://doi.org/10.1002/jcb.26537

44. Yang QS, Li B, Xu G, Yang SQ, Wang P, Tang HH, Liu YY (2019) Long noncoding RNA LINC00483/microRNA-144 regulates radiosensitivity and epithelial-mesenchymal transition in lung adenocarcinoma by interacting with HOXA10. J Cell Physiol 234(7):11805-11821. https://doi.org/10.1002/jcp.27886

45. Liang R, Xiao G, Wang M, Li X, Li Y, Hui Z, Sun X, Qin S, Zhang B, Du N, Liu D, Ren H (2018) SNHG6 functions as a competing endogenous RNA to regulate E2F7 expression by sponging miR-26a-5p in lung adenocarcinoma. Biomed Pharmacother 107:1434-1446. https://doi.org/10.1016/j.bioph a.2018.08.099

46. Cao Y, Luo X, Ding X, Cui S, Guo C (2018) LncRNA ATB promotes proliferation and metastasis in A549 cells by downregulation of microRNA-494. J Cell Biochem 119(8):6935-6942. https://doi.org/10.1002/jcb.26894

47. Yao Z, Fenoglio S, Gao DC, Camiolo M, Stiles B, Lindsted T, Schlederer M, Johns C, Altorki N, Mittal V, Kenner L, Sordella R (2010) TGF-beta IL-6 axis mediates selective and adaptive mechanisms of resistance to molecular targeted therapy in lung cancer. Proc Natl Acad Sci USA 107(35):15535-15540. https:// doi.org/10.1073/pnas.1009472107

48. Sakai S, Ohhata T, Kitagawa K, Uchida C, Aoshima T, Niida H, Suzuki T, Inoue Y, Miyazawa K, Kitagawa M (2019) Long noncoding RNA ELIT-1 acts as a Smad3 cofactor to facilitate TGFbeta/Smad signaling and promote epithelial-mesenchymal transition. Cancer Res 79(11):2821-2838. https://doi. org/10.1158/0008-5472.CAN-18-3210

49. Lu Z, Li Y, Che Y, Huang J, Sun S, Mao S, Lei Y, Li N, Sun N, He J (2018) The TGFbeta-induced lncRNA TBILA promotes non-small cell lung cancer progression in vitro and in vivo via cis-regulating HGAL and activating S100A7/JAB1 signaling. Cancer Lett 432:156-168. https://doi.org/10.1016/j.canle t.2018.06.013

50. Zhang C, Hao Y, Wang Y, Xu J, Teng Y, Yang X (2018) TGFbeta/SMAD4-regulated LncRNA-LINP1 inhibits epithelial-mesenchymal transition in lung cancer. Int J Biol Sci 14(12):17151723. https://doi.org/10.7150/ijbs.27197

51. Ren Y, Jia HH, Xu YQ, Zhou X, Zhao XH, Wang YF, Song X, Zhu ZY, Sun T, Dou Y, Tian WP, Zhao XL, Kang CS, Mei M (2018) Paracrine and epigenetic control of CAF-induced metastasis: the role of HOTAIR stimulated by TGF-ss1 secretion. Mol Cancer 17(1):5. https://doi.org/10.1186/s12943-018-0758-4

52. Kawasaki N, Miwa T, Hokari S, Sakurai T, Ohmori K, Miyauchi K, Miyazono K, Koinuma D (2018) Long noncoding RNA
NORAD regulates transforming growth factor-beta signaling and epithelial-to-mesenchymal transition-like phenotype. Cancer Sci 109(7):2211-2220. https://doi.org/10.1111/cas.13626

53. Terashima M, Tange S, Ishimura A, Suzuki T (2017) MEG3 Long noncoding RNA contributes to the epigenetic regulation of epithelial-mesenchymal transition in lung cancer cell lines. J Biol Chem 292(1):82-99. https://doi.org/10.1074/jbc.M116.750950

54. Lu L, Luo F, Liu Y, Liu X, Shi L, Lu X, Liu Q (2015) Posttranscriptional silencing of the lncRNA MALAT1 by miR-217 inhibits the epithelial-mesenchymal transition via enhancer of zeste homolog 2 in the malignant transformation of HBE cells induced by cigarette smoke extract. Toxicol Appl Pharmacol 289(2):276-285. https://doi.org/10.1016/j.taap.2015.09.016

55. He R, Zhang FH, Shen N (2017) LncRNA FEZF1-AS1 enhances epithelial-mesenchymal transition (EMT) through suppressing E-cadherin and regulating WNT pathway in non-small cell lung cancer (NSCLC). Biomed Pharmacother 95:331-338. https://doi. org/10.1016/j.biopha.2017.08.057

56. Chen JH, Zhou LY, Xu S, Zheng YL, Wan YF, Hu CP (2017) Overexpression of IncRNA HOXA11-AS promotes cell epithelial-mesenchymal transition by repressing miR-200b in non-small cell lung cancer. Cancer Cell Int 17:64. https://doi.org/10.1186/ s12935-017-0433-7

57. Wu Y, Lyu H, Liu H, Shi X, Song Y, Liu B (2016) Downregulation of the long noncoding RNA GAS5-AS1 contributes to tumor metastasis in non-small cell lung cancer. Sci Rep 6:31093. https ://doi.org/10.1038/srep31093

58. Sun M, Liu XH, Wang KM, Nie FQ, Kong R, Yang JS, Xia R, Xu TP, Jin FY, Liu ZJ, Chen JF, Zhang EB, De W, Wang ZX (2014) Downregulation of BRAF activated non-coding RNA is associated with poor prognosis for non-small cell lung cancer and promotes metastasis by affecting epithelial-mesenchymal transition. Mol Cancer 13:68. https://doi.org/10.1186/1476-4598-13-68

59. Lu Z, Li Y, Wang J, Che Y, Sun S, Huang J, Chen Z, He J (2017) Long non-coding RNA NKILA inhibits migration and invasion of non-small cell lung cancer via NF-kappaB/Snail pathway. J Exp Clin Cancer Res 36(1):54. https://doi.org/10.1186/s1304 6-017-0518-0

60. Hao Y, Yang X, Zhang D, Luo J, Chen R (2017) Long noncoding RNA LINC01186, regulated by TGF-beta/SMAD3, inhibits migration and invasion through epithelial-mesenchymal-transition in lung cancer. Gene 608:1-12. https://doi.org/10.1016/j. gene.2017.01.023

61. Balaban NQ, Gerdes K, Lewis K, McKinney JD (2013) A problem of persistence: still more questions than answers? Nat Rev Microbiol 11(8):587-591. https://doi.org/10.1038/nrmicro3076

62. Sanchez-Danes A, Larsimont JC, Liagre M, Munoz-Couselo E, Lapouge G, Brisebarre A, Dubois C, Suppa M, Sukumaran V, Del Marmol V, Tabernero J, Blanpain C (2018) A slowcycling LGR5 tumour population mediates basal cell carcinoma relapse after therapy. Nature 562(7727):434-438. https://doi. org/10.1038/s41586-018-0603-3

63. Schmitt AM, Chang HY (2016) Long noncoding RNAs in cancer pathways. Cancer Cell 29(4):452-463. https://doi.org/10.1016/j. ccell.2016.03.010

64. Dimitrova N, Zamudio JR, Jong RM, Soukup D, Resnick R, Sarma K, Ward AJ, Raj A, Lee JT, Sharp PA, Jacks T (2014) LincRNA-p21 activates p21 in cis to promote Polycomb target gene expression and to enforce the G1/S checkpoint. Mol Cell 54(5):777-790. https://doi.org/10.1016/j.molcel.2014.04.025

65. Schmitt AM, Garcia JT, Hung T, Flynn RA, Shen Y, Qu K, Payumo AY, Peres-da-Silva A, Broz DK, Baum R, Guo S, Chen JK, Attardi LD, Chang HY (2016) An inducible long noncoding RNA amplifies DNA damage signaling. Nat Genet 48(11):13701376. https://doi.org/10.1038/ng.3673 
66. Jiang J, Gu Y, Liu J, Wu R, Fu L, Zhao J, Guan Y (2016) Coexistence of p16/CDKN2A homozygous deletions and activating EGFR mutations in lung adenocarcinoma patients signifies a poor response to EGFR-TKIs. Lung Cancer 102:101-107. https ://doi.org/10.1016/j.lungcan.2016.10.015

67. Montes M, Nielsen MM, Maglieri G, Jacobsen A, Hojfeldt J, Agrawal-Singh S, Hansen K, Helin K, van de Werken HJG, Pedersen JS, Lund AH (2015) The lncRNA MIR31HG regulates p16(INK4A) expression to modulate senescence. Nat Commun 6:6967. https://doi.org/10.1038/ncomms7967

68. Yu W, Gius D, Onyango P, Muldoon-Jacobs K, Karp J, Feinberg AP, Cui H (2008) Epigenetic silencing of tumour suppressor gene p15 by its antisense RNA. Nature 451(7175):202-206. https:// doi.org/10.1038/nature06468

69. Sun Q, Tripathi V, Yoon JH, Singh DK, Hao Q, Min KW, Davila S, Zealy RW, Li XL, Polycarpou-Schwarz M, Lehrmann E, Zhang Y, Becker KG, Freier SM, Zhu Y, Diederichs S, Prasanth SG, Lal A, Gorospe M, Prasanth KV (2018) MIR100 host gene-encoded lncRNAs regulate cell cycle by modulating the interaction between HuR and its target mRNAs. Nucleic Acids Res 46(19):10405-10416. https://doi.org/10.1093/nar/gky696

70. Yeh CH, Bellon M, Nicot C (2018) FBXW7: a critical tumor suppressor of human cancers. Mol Cancer 17(1):115. https://doi. org/10.1186/s12943-018-0857-2

71. Xu M, Chen X, Lin K, Zeng K, Liu X, Pan B, Xu X, Xu T, Hu X, Sun L, He B, Pan Y, Sun H, Wang S (2018) The long noncoding RNA SNHG1 regulates colorectal cancer cell growth through interactions with EZH2 and miR-154-5p. Mol Cancer 17(1):141. https://doi.org/10.1186/s12943-018-0894-x

72. Beltran H, Prandi D, Mosquera JM, Benelli M, Puca L, Cyrta J, Marotz C, Giannopoulou E, Chakravarthi BV, Varambally S, Tomlins SA, Nanus DM, Tagawa ST, Van Allen EM, Elemento O, Sboner A, Garraway LA, Rubin MA, Demichelis F (2016) Divergent clonal evolution of castration-resistant neuroendocrine prostate cancer. Nat Med 22(3):298-305. https://doi.org/10.1038/ nm.4045

73. Dardenne E, Beltran H, Benelli M, Gayvert K, Berger A, Puca L, Cyrta J, Sboner A, Noorzad Z, MacDonald T, Cheung C, Yuen KS, Gao D, Chen Y, Eilers M, Mosquera JM, Robinson BD, Elemento O, Rubin MA, Demichelis F, Rickman DS (2016) N-Myc Induces an EZH2-Mediated Transcriptional Program Driving Neuroendocrine Prostate Cancer. Cancer Cell 30(4):563-577. https://doi.org/10.1016/j.ccell.2016.09.005

74. Lim JS, Ibaseta A, Fischer MM, Cancilla B, O'Young G, Cristea S, Luca VC, Yang D, Jahchan NS, Hamard C, Antoine M, Wislez M, Kong C, Cain J, Liu YW, Kapoun AM, Garcia KC, Hoey T, Murriel CL, Sage J (2017) Intratumoural heterogeneity generated by Notch signalling promotes small-cell lung cancer. Nature 545(7654):360-364. https://doi.org/10.1038/nature22323

75. Ballas N, Grunseich C, Lu DD, Speh JC, Mandel G (2005) REST and its corepressors mediate plasticity of neuronal gene chromatin throughout neurogenesis. Cell 121(4):645-657. https://doi. org/10.1016/j.cell.2005.03.013

76. Lim JS, Ibaseta A, Fischer MM, Cancilla B, O'Young G, Cristea S, Luca VC, Yang D, Jahchan NS, Hamard C, Antoine M, Wislez M, Kong C, Cain J (2017) Intratumoural heterogeneity generated by Notch signalling promotes small-cell lung cancer. Nature 545(7654):360-364. https://doi.org/10.1038/nature2232 3

77. Santos M, Martinez-Fernandez M, Duenas M, Garcia-Escudero R, Alfaya B, Villacampa F, Saiz-Ladera C, Costa C, Oteo M, Duarte J, Martinez V, Gomez-Rodriguez MJ, Martin ML, Fernandez M, Viatour P, Morcillo MA, Sage J, Castellano D, Rodriguez-Peralto JL, de la Rosa F, Paramio JM (2014) In vivo disruption of an Rb-E2F-Ezh2 signaling loop causes bladder cancer.
Cancer Res 74(22):6565-6577. https://doi.org/10.1158/00085472.CAN-14-1218

78. Wang L, Zhang X, Liu Y, Xu S (2019) Long noncoding RNA FBXL19-AS1 induces tumor growth and metastasis by sponging miR-203a-3p in lung adenocarcinoma. J Cell Physiol. https://doi. org/10.1002/jcp. 29251

79. Sarkar A, Hochedlinger K (2013) The sox family of transcription factors: versatile regulators of stem and progenitor cell fate. Cell Stem Cell 12(1):15-30. https://doi.org/10.1016/j. stem.2012.12.007

80. Bishop JL, Thaper D, Vahid S, Davies A, Ketola K, Kuruma H, Jama R, Nip KM, Angeles A, Johnson F, Wyatt AW, Fazli L, Gleave ME, Lin D, Rubin MA, Collins CC, Wang Y, Beltran H, Zoubeidi A (2017) The Master neural transcription factor BRN2 Is an androgen receptor-suppressed driver of neuroendocrine differentiation in prostate cancer. Cancer Discov 7(1):54-71. https ://doi.org/10.1158/2159-8290.CD-15-1263

81. Sakaeda M, Sato H, Ishii J, Miyata C, Kamma H, Shishido-Hara Y, Shimoyamada H, Fujiwara M, Endo T, Tanaka R, Kondo H, Goya T, Aoki I, Yazawa T (2013) Neural lineage-specific homeoprotein BRN2 is directly involved in TTF1 expression in small-cell lung cancer. Lab Invest 93(4):408-421. https://doi. org/10.1038/labinvest.2013.2

82. Chen C, NoTKIns AL, Lan MS (2019) Insulinoma-associated-1: from neuroendocrine tumor marker to cancer therapeutics. Mol Cancer Res 17(8):1597-1604. https://doi.org/10.1158/15417786.MCR-19-0286

83. Ahmad A, Strohbuecker S, Tufarelli C, Sottile V (2017) Expression of a SOX1 overlapping transcript in neural differentiation and cancer models. Cell Mol Life Sci 74(22):4245-4258. https ://doi.org/10.1007/s00018-017-2580-3

84. Saghaeian Jazi M, Samaei NM, Ghanei M, Shadmehr MB, Mowla SJ (2016) Identification of new SOX2OT transcript variants highly expressed in human cancer cell lines and down regulated in stem cell differentiation. Mol Biol Rep 43(2):65-72. https://doi.org/10.1007/s11033-015-3939-x

85. Shahryari A, Jazi MS, Samaei NM, Mowla SJ (2015) Long noncoding RNA SOX2OT: expression signature, splicing patterns, and emerging roles in pluripotency and tumorigenesis. Front Genet 6:196. https://doi.org/10.3389/fgene.2015.00196

86. Shahryari A, Rafiee MR, Fouani Y, Oliae NA, Samaei NM, Shafiee M, Semnani S, Vasei M, Mowla SJ (2014) Two novel splice variants of SOX2OT, SOX2OT-S1, and SOX2OT-S2 are coupregulated with SOX2 and OCT4 in esophageal squamous cell carcinoma. Stem Cells 32(1):126-134. https://doi. org/10.1002/stem.1542

87. Kim JT, Liu C, Zaytseva YY, Weiss HL, Townsend CM Jr, Evers BM (2015) Neurotensin, a novel target of Wnt/beta-catenin pathway, promotes growth of neuroendocrine tumor cells. Int J Cancer 136(6):1475-1481. https://doi.org/10.1002/ijc.29123

88. Meder L, Konig K, Ozretic L, Schultheis AM, Ueckeroth F, Ade CP, Albus K, Boehm D, Rommerscheidt-Fuss U, Florin A, Buhl T, Hartmann W, Wolf J, Merkelbach-Bruse S, Eilers M, Perner S, Heukamp LC, Buettner R (2016) NOTCH, ASCL1, p53 and RB alterations define an alternative pathway driving neuroendocrine and small cell lung carcinomas. Int J Cancer 138(4):927-938. https://doi.org/10.1002/ijc.29835

89. Tenjin Y, Kudoh S, Kubota S, Yamada T, Matsuo A, Sato Y, Ichimura T, Kohrogi H, Sashida G, Sakagami T, Ito T (2019) Ascl1-induced Wnt 11 regulates neuroendocrine differentiation, cell proliferation, and E-cadherin expression in small-cell lung cancer and Wnt11 regulates small-cell lung cancer biology. Lab Invest 99(11):1622-1635. https://doi.org/10.1038/s4137 4-019-0277-y 
90. Osada H, Tomida S, Yatabe Y, Tatematsu Y, Takeuchi T, Murakami H, Kondo Y, Sekido Y, Takahashi T (2008) Roles of achaete-scute homologue 1 in DKK1 and E-cadherin repression and neuroendocrine differentiation in lung cancer. Cancer Res 68(6):1647-1655. https://doi.org/10.1158/0008-5472. CAN-07-5039

91. Rong L, Zhao R, Lu J (2017) Highly expressed long non-coding RNA FOXD2-AS1 promotes non-small cell lung cancer progression via Wnt/beta-catenin signaling. Biochem Biophys Res Commun 484(3):586-591. https://doi.org/10.1016/j.bbrc.2017.01.141

92. Shi SL, Zhang ZH (2019) Long non-coding RNA SNHG1 contributes to cisplatin resistance in non-small cell lung cancer by regulating miR-140-5p/Wnt/beta-catenin pathway. Neoplasma 66(5):756-765. https://doi.org/10.4149/neo_2018_181218N980

93. Guan H, Zhu T, Wu S, Liu S, Liu B, Wu J, Cai J, Zhu X, Zhang X, Zeng M, Li J, Song E, Li M (2019) Long noncoding RNA LINC00673-v4 promotes aggressiveness of lung adenocarcinoma via activating WNT/beta-catenin signaling. Proc Natl Acad Sci USA 116(28):14019-14028. https://doi.org/10.1073/ pnas. 1900997116

94. Jiang P, Xu H, Xu C, Chen A, Chen L, Zhou M, Haq IU, Wu X, Mariyam Z, Feng Q (2018) NEAT1 contributes to the CSC-like traits of A549/CDDP cells via activating Wnt signaling pathway. Chem Biol Interact 296:154-161. https://doi. org/10.1016/j.cbi.2018.10.001

95. Sun SJ, Lin Q, Ma JX, Shi WW, Yang B, Li F (2017) Long non-coding RNA NEAT1 acts as oncogene in NSCLC by regulating the Wnt signaling pathway. Eur Rev Med Pharmacol Sci 21(3):504-510

96. Chang KT, Tsai CM, Chiou YC, Chiu CH, Jeng KS, Huang CY (2005) IL-6 induces neuroendocrine dedifferentiation and cell proliferation in non-small cell lung cancer cells. Am J Physiol Lung Cell Mol Physiol 289(3):L446-453. https://doi. org/10.1152/ajplung.00089.2005

97. Liu L, Liu L, Lu S (2019) lncRNA H19 promotes viability and epithelial-mesenchymal transition of lung adenocarcinoma cells by targeting miR-29b-3p and modifying STAT3. Int J Oncol 54(3):929-941. https://doi.org/10.3892/ijo.2019.4695

98. Li S, Mei Z, Hu HB, Zhang X (2018) The lncRNA MALAT1 contributes to non-small cell lung cancer development via modulating miR-124/STAT3 axis. J Cell Physiol 233(9):6679_ 6688. https://doi.org/10.1002/jcp.26325

99. Huang Z, Lei W, Hu HB, Zhang H, Zhu Y (2018) H19 promotes non-small-cell lung cancer (NSCLC) development through STAT3 signaling via sponging miR-17. J Cell Physiol 233(10):6768-6776. https://doi.org/10.1002/jcp.26530

100. Wang Y, Han D, Pan L, Sun J (2018) The positive feedback between lncRNA TNK2-AS1 and STAT3 enhances angiogenesis in non-small cell lung cancer. Biochem Biophys Res Commun 507(1-4):185-192. https://doi.org/10.1016/j. bbrc.2018.11.004

101. Chen X, Song E (2019) Turning foes to friends: targeting cancerassociated fibroblasts. Nat Rev Drug Discov 18(2):99-115. https ://doi.org/10.1038/s41573-018-0004-1

102. Liu T, Han C, Wang S, Fang P, Ma Z, Xu L, Yin R (2019) Cancer-associated fibroblasts: an emerging target of anti-cancer immunotherapy. J Hematol Oncol 12(1):86. https://doi. org/10.1186/s13045-019-0770-1

103. Choe C, Shin YS, Kim C, Choi SJ, Lee J, Kim SY, Cho YB, Kim J (2015) Crosstalk with cancer-associated fibroblasts induces resistance of non-small cell lung cancer cells to epidermal growth factor receptor tyrosine kinase inhibition. Onco Targets Ther 8:3665-3678. https://doi.org/10.2147/OTT.S89659

104. Yoshida T, Ishii G, Goto K, Neri S, Hashimoto H, Yoh K, Niho S, Umemura S, Matsumoto S, Ohmatsu H, Iida S, Niimi A, Nagai K, Ohe Y, Ochiai A (2015) Podoplanin-positive cancer-associated fibroblasts in the tumor microenvironment induce primary resistance to EGFR-TKIs in lung adenocarcinoma with EGFR mutation. Clin Cancer Res 21(3):642-651. https://doi.org/10.1158/1078-0432.CCR-14-0846

105. Apicella M, Giannoni E, Fiore S, Ferrari KJ, Fernandez-Perez D, Isella C, Granchi C, Minutolo F, Sottile A, Comoglio PM, Medico E, Pietrantonio F, Volante M, Pasini D, Chiarugi P, Giordano $S$, Corso S (2018) Increased lactate secretion by cancer cells sustains non-cell-autonomous adaptive resistance to MET and EGFR targeted therapies. Cell Metab 28(6):848-865. https://doi. org/10.1016/j.cmet.2018.08.006 ((e846))

106. Suzuki E, Yamazaki S, Naito T, Hashimoto H, Okubo S, Udagawa H, Goto K, Tsuboi M, Ochiai A, Ishii G (2019) Secretion of high amounts of hepatocyte growth factor is a characteristic feature of cancer-associated fibroblasts with EGFR-TKI resistancepromoting phenotype: A study of 18 cases of cancer-associated fibroblasts. Pathol Int 69(8):472-480. https://doi.org/10.1111/ pin. 12838

107. Engelman JA, Zejnullahu K, Mitsudomi T, Song Y, Hyland C, Park JO, Lindeman N, Gale CM, Zhao X, Christensen J, Kosaka T, Holmes AJ, Rogers AM, Cappuzzo F, Mok T, Lee C, Johnson BE, Cantley LC, Janne PA (2007) MET amplification leads to gefitinib resistance in lung cancer by activating ERBB3 signaling. Science 316(5827):1039-1043. https://doi.org/10.1126/scien ce. 1141478

108. Karachaliou N, Codony-Servat J, Teixido C, Pilotto S, Drozdowskyj A, Codony-Servat C, Gimenez-Capitan A, MolinaVila MA, Bertran-Alamillo J, Gervais R, Massuti B, Moran T, Majem M, Felip E, Carcereny E, Garcia-Campelo R, Viteri S, Gonzalez-Cao M, Morales-Espinosa D, Verlicchi A, Crisetti E, Chaib I, Santarpia M, Luis Ramirez J, Bosch-Barrera J, Felipe Cardona A, de Marinis F, Lopez-Vivanco G, Miguel Sanchez J, Vergnenegre A, Sanchez Hernandez JJ, Sperduti I, Bria E, Rosell R (2015) BIM and mTOR expression levels predict outcome to erlotinib in EGFR-mutant non-small-cell lung cancer. Sci Rep 5:17499. https://doi.org/10.1038/srep17499

109. Wang Y, Zhang T, Guo L, Ren T, Yang Y (2019) Stromal extracellular matrix is a microenvironmental cue promoting resistance to EGFR tyrosine kinase inhibitors in lung cancer cells. Int J Biochem Cell Biol 106:96-106. https://doi.org/10.1016/j.bioce 1.2018.11.001

110. Wang LC, Lo A, Scholler J, Sun J, Majumdar RS, Kapoor V, Antzis M, Cotner CE, Johnson LA, Durham AC, Solomides CC, June CH, Pure E, Albelda SM (2014) Targeting fibroblast activation protein in tumor stroma with chimeric antigen receptor $\mathrm{T}$ cells can inhibit tumor growth and augment host immunity without severe toxicity. Cancer Immunol Res 2(2):154-166. https ://doi.org/10.1158/2326-6066.CIR-13-0027

111. Zhang B, Zhang Y, Zhao J, Wang Z, Wu T, Ou W, Wang J, Yang B, Zhao Y, Rao Z, Gao J (2014) M2-polarized macrophages contribute to the decreased sensitivity of EGFR-TKIs treatment in patients with advanced lung adenocarcinoma. Med Oncol 31(8):127. https://doi.org/10.1007/s12032-014-0127-0

112. Choi H, Sheng J, Gao D, Li F, Durrans A, Ryu S, Lee SB, Narula N, Rafii S, Elemento O, Altorki NK, Wong ST, Mittal V (2015) Transcriptome analysis of individual stromal cell populations identifies stroma-tumor crosstalk in mouse lung cancer model. Cell Rep 10(7):1187-1201. https://doi.org/10.1016/j.celre p.2015.01.040

113. Che D, Zhang S, Jing Z, Shang L, Jin S, Liu F, Shen J, Li Y, Hu J, Meng Q, Yu Y (2017) Macrophages induce EMT to promote invasion of lung cancer cells through the IL-6-mediated COX-2/ PGE2/beta-catenin signalling pathway. Mol Immunol 90:197210. https://doi.org/10.1016/j.molimm.2017.06.018

114. Sun Y, Xu J (2019) TCF-4 Regulated lncRNA-XIST promotes M2 polarization of macrophages and is associated with 
lung cancer. Onco Targets Ther 12:8055-8062. https://doi. org/10.2147/OTT.S210952

115. Li Z, Feng C, Guo J, Hu X, Xie D (2019) GNAS-AS1/miR-4319/ NECAB3 axis promotes migration and invasion of non-small cell lung cancer cells by altering macrophage polarization. Funct Integr Genomics. https://doi.org/10.1007/s10142-019-00696-x

116. Murakami A, Takahashi F, Nurwidya F, Kobayashi I, Minakata K, Hashimoto M, Nara T, Kato M, Tajima K, Shimada N, Iwakami S, Moriyama M, Moriyama H, Koizumi F, Takahashi K (2014) Hypoxia increases gefitinib-resistant lung cancer stem cells through the activation of insulin-like growth factor 1 receptor. PLoS ONE 9(1):e86459. https://doi.org/10.1371/journ al.pone. 0086459

117. Minakata K, Takahashi F, Nara T, Hashimoto M, Tajima K, Murakami A, Nurwidya F, Yae S, Koizumi F, Moriyama H, Seyama K, Nishio K, Takahashi K (2012) Hypoxia induces gefitinib resistance in non-small-cell lung cancer with both mutant and wild-type epidermal growth factor receptors. Cancer Sci 103(11):1946-1954. https://doi.org/10.111 1/j.1349-7006.2012.02408.x

118. Michalik KM, You X, Manavski Y, Doddaballapur A, Zornig M, Braun T, John D, Ponomareva Y, Chen W, Uchida S, Boon RA, Dimmeler S (2014) Long noncoding RNA MALAT1 regulates endothelial cell function and vessel growth. Circ Res 114(9):1389-1397. https://doi.org/10.1161/CIRCRESAHA .114 .303265

119. Yin W, Yu X, Kang X, Zhao Y, Zhao P, Jin H, Fu X, Wan Y, Peng C, Huang Y (2018) Remodeling tumor-associated macrophages and neovascularization overcomes EGFR(T790M)associated drug resistance by PD-L1 nanobody-mediated codelivery. Small 14(47):e1802372. https://doi.org/10.1002/ smll.201802372

120. Yang GJ, Ko CN, Zhong HJ, Leung CH, Ma DL (2019) Structure-based discovery of a selective KDM5A inhibitor that exhibits anti-cancer activity via inducing cell cycle arrest and senescence in breast cancer cell lines. Cancers (Basel). https ://doi.org/10.3390/cancers11010092

121. Guler GD, Tindell CA, Pitti R, Wilson C, Nichols K, KaiWai Cheung T, Kim HJ, Wongchenko M, Yan Y, Haley B, Cuellar T, Webster J, Alag N, Hegde G, Jackson E, Nance TL, Giresi PG, Chen KB, Liu J, Jhunjhunwala S, Settleman J, Stephan JP, Arnott D, Classon M (2017) Repression of stress-induced LINE-1 expression protects cancer cell subpopulations from lethal drug exposure. Cancer Cell 32(2):221-237. https://doi. org/10.1016/j.ccell.2017.07.002 ((e213))

122. McKeithen D, Graham T, Chung LW, Odero-Marah V (2010) Snail transcription factor regulates neuroendocrine differentiation in LNCaP prostate cancer cells. Prostate 70(9):982-992. https://doi.org/10.1002/pros.21132

123. Liau BB, Sievers C, Donohue LK, Gillespie SM, Flavahan WA, Miller TE, Venteicher AS, Hebert CH, Carey CD, Rodig SJ, Shareef SJ, Najm FJ, van Galen P, Wakimoto H, Cahill DP, Rich JN, Aster JC, Suva ML, Patel AP, Bernstein BE (2017) Adaptive chromatin remodeling drives glioblastoma stem cell plasticity and drug tolerance. Cell Stem Cell 20(2):233-246. https://doi.org/10.1016/j.stem.2016.11.003 ((e237))

124. Kruidenier L, Chung CW, Cheng Z, Liddle J, Che K, Joberty G, Bantscheff M, Bountra C, Bridges A, Diallo H, Eberhard D, Hutchinson S, Jones E, Katso R, Leveridge M, Mander PK, Mosley J, Ramirez-Molina C, Rowland P, Schofield CJ, Sheppard RJ, Smith JE, Swales C, Tanner R, Thomas P, Tumber A, Drewes G, Oppermann U, Patel DJ, Lee K, Wilson DM (2012) A selective jumonji H3K27 demethylase inhibitor modulates the proinflammatory macrophage response. Nature 488(7411):404-408. https://doi.org/10.1038/nature11262
125. Knutson SK, Kawano S, Minoshima Y, Warholic NM, Huang KC, Xiao Y, Kadowaki T, Uesugi M, Kuznetsov G, Kumar N, Wigle TJ, Klaus CR, Allain CJ, Raimondi A, Waters NJ, Smith JJ, Porter-Scott M, Chesworth R, Moyer MP, Copeland RA, Richon VM, Uenaka T, Pollock RM, Kuntz KW, Yokoi A, Keilhack H (2014) Selective inhibition of EZH2 by EPZ6438 leads to potent antitumor activity in EZH2-mutant nonHodgkin lymphoma. Mol Cancer Ther 13(4):842-854. https:// doi.org/10.1158/1535-7163.MCT-13-0773

126. Vaswani RG, Gehling VS, Dakin LA, Cook AS, Nasveschuk CG, Duplessis M, Iyer P, Balasubramanian S, Zhao F, Good AC, Campbell R, Lee C, Cantone N, Cummings RT, Normant E, Bellon SF, Albrecht BK, Harmange JC, Trojer P, Audia JE, Zhang Y, Justin N, Chen S, Wilson JR, Gamblin SJ (2016) Identification of (R)-N-((4-methoxy-6-methyl-2-oxo1,2-dihydropyridin-3-yl)methyl)-2-methyl-1-(1-(1 -(2,2,2-trifluoroethyl)piperidin-4-yl)ethyl)-1H-indole-3-carboxamide (CPI-1205), a potent and selective inhibitor of histone methyltransferase EZH2, suitable for phase I clinical trials for B-cell lymphomas. J Med Chem 59(21):9928-9941. https:// doi.org/10.1021/acs.jmedchem.6b01315

127. Zhang H, Qi J, Reyes JM, Li L, Rao PK, Li F, Lin CY, Perry JA, Lawlor MA, Federation A, De Raedt T, Li YY, Liu Y, Duarte MA, Zhang Y, Herter-Sprie GS, Kikuchi E, Carretero J, Perou CM, Reibel JB, Paulk J, Bronson RT, Watanabe H, Brainson CF, Kim CF, Hammerman PS, Brown M, Cichowski K, Long H, Bradner JE, Wong KK (2016) Oncogenic deregulation of EZH2 as an opportunity for targeted therapy in lung cancer. Cancer Discov 6(9):1006-1021. https://doi.org/10.1158/21598290.CD-16-0164

128. Frankel AE, Liu X, Minna JD (2016) Developing EZH2-targeted therapy for lung cancer. Cancer Discov 6(9):949-952. https://doi.org/10.1158/2159-8290.CD-16-0800

129. Gong H, Yuan Y, Li Y, Zhang H, Li Y, Li W, Wang P, Shi R, Liu C, Cui L, Liu H, Chen J (2019) Role of EZH2 inhibitor combined with gefitinib in EGFR-TKIs resistant lung cancer cells. Zhongguo Fei Ai Za Zhi 22(5):255-263. https://doi. org/10.3779/j.issn.1009-3419.2019.05.01

130. Weng CH, Chen LY, Lin YC, Shih JY, Lin YC, Tseng RY, Chiu AC, Yeh YH, Liu C, Lin YT, Fang JM, Chen CC (2019) Epithelial-mesenchymal transition (EMT) beyond EGFR mutations per se is a common mechanism for acquired resistance to EGFR TKI. Oncogene 38(4):455-468. https://doi.org/10.1038/ s41388-018-0454-2

131. Bates SE (2020) Epigenetic therapies for cancer. N Engl J Med 383(7):650-663. https://doi.org/10.1056/NEJMra1805035

132. Mohammad HP, Barbash O, Creasy CL (2019) Targeting epigenetic modifications in cancer therapy: erasing the roadmap to cancer. Nat Med 25(3):403-418. https://doi.org/10.1038/s4159 1-019-0376-8

133. Washietl S, Kellis M, Garber M (2014) Evolutionary dynamics and tissue specificity of human long noncoding RNAs in six mammals. Genome Res 24(4):616-628. https://doi. org/10.1101/gr.165035.113

134. Huarte $M$ (2015) The emerging role of lncRNAs in cancer. Nat Med 21(11):1253-1261. https://doi.org/10.1038/nm.3981

135. Ling H, Fabbri M, Calin GA (2013) MicroRNAs and other non-coding RNAs as targets for anticancer drug development. Nat Rev Drug Discov 12(11):847-865. https://doi.org/10.1038/ $\operatorname{nrd} 4140$

136. Gutschner T, Baas M, Diederichs S (2011) Noncoding RNA gene silencing through genomic integration of RNA destabilizing elements using zinc finger nucleases. Genome Res 21(11):1944-1954. https://doi.org/10.1101/gr.122358.111 
137. Esposito R, Bosch N, Lanzos A, Polidori T, Pulido-Quetglas C, Johnson R (2019) Hacking the cancer genome: profiling therapeutically actionable long non-coding RNAs using CRISPR-Cas9 screening. Cancer Cell 35(4):545-557. https:// doi.org/10.1016/j.ccell.2019.01.019

138. Goyal A, Myacheva K, Gross M, Klingenberg M, Duran Arque B, Diederichs S (2017) Challenges of CRISPR/Cas9 applications for long non-coding RNA genes. Nucleic Acids Res 45(3):e12. https://doi.org/10.1093/nar/gkw883

139. Ferrer L, Giaj Levra M, Brevet M, Antoine M, Mazieres J, Rossi G, Chiari R, Westeel V, Poudenx M, Letreut J, Gervais R, Osman G, Girard N, Toffart AC, Novello S, Moro-Sibilot D (2019) A brief report of transformation from NSCLC to SCLC: molecular and therapeutic characteristics. J Thorac Oncol 14(1):130-134. https://doi.org/10.1016/j.jtho.2018.08.2028
140. Qiu M, Xia W, Chen R, Wang S, Xu Y, Ma Z, Xu W, Zhang E, Wang J, Fang T, Hu J, Dong G, Yin R, Wang J, Xu L (2018) The circular RNA circPRKCI promotes tumor growth in lung adenocarcinoma. Cancer Res 78(11):2839-2851. https://doi. org/10.1158/0008-5472.CAN-17-2808

141. Sheridan C (2013) First Axl inhibitor enters clinical trials. Nat Biotechnol 31(9):775-776. https://doi.org/10.1038/nbt0913-775a

Publisher's Note Springer Nature remains neutral with regard to jurisdictional claims in published maps and institutional affiliations. 